\title{
Effect of thermoclines and turbulence on depth of larval settlement and spat recruitment of the giant scallop Placopecten magellanicus in $9.5 \mathrm{~m}$ deep laboratory mesocosms*
}

\author{
Christopher M. Pearce ${ }^{1,2, * *}$, Scott M. Gallager ${ }^{3}$, Joan L. Manuel ${ }^{2}$, \\ Darlene A. Manning ${ }^{2}$, Ron K. O'Dor ${ }^{2}$, Edwin Bourget ${ }^{1}$ \\ ${ }^{1}$ GIROQ, Département de Biologie, Université Laval, Sainte-Foy, Québec G1K 7P4, Canada \\ ${ }^{2}$ Department of Biology, Dalhousie University, Halifax, Nova Scotia B3H 4J1, Canada \\ ${ }^{3}$ Department of Biology, Woods Hole Oceanographic Institution, Woods Hole, Massachusetts 02543, USA
}

\begin{abstract}
An experiment was conducted from December 1992 to February 1993 in a $10.5 \mathrm{~m}$ deep, $3.7 \mathrm{~m}$ diameter tank to examine the effect of thermoclines and water column turbulence on the depth of larval settlement and spat recruitment of the giant scallop Placopecten magellanicus (Gmelin). Polyethylene tube mesocosms set up within the tank were used to enclose $9.5 \mathrm{~m}$ deep columns of seawater which were then used as experimental replicates. Five different treatments were established as follows: (1) no turbulence and a $1.5^{\circ} \mathrm{C}$ thermocline, (2) no turbulence and no thermal gradient, (3) low level of turbulence with a $1.5^{\circ} \mathrm{C}$ thermocline, (4) medium level of turbulence with a $0.5^{\circ} \mathrm{C}$ thermocline, and (5) high level of turbulence with no thermal gradient. Various turbulence levels simulated turbulext energies ranging from open oceanic environments to near-shore and coastal conditions with vertical dissipation rates ranging from $10^{-7}$ to $10^{-3} \mathrm{~cm}^{2} \mathrm{~s}^{-3}$. Ropes with collectors positioned at every $1 \mathrm{~m}$ depth interval were suspended the length of the water column in each replicate tube to collect settled spat. Spat counts varied significantly with both depth and turbulence treatment and were dependent on the interaction between the 2 factors. Numbers of spat generally increased with increasing depth in the static and low turbulence treatments, but this relationship became less evident with increasing turbulence; spat recruitment in the high turbulence tubes appeared random with respect to depth. It is suggested that the trend of increasing recruitment with depth in the static and low turbulence tubes was driven primarily by larval behaviour at settlement. There was no indication of increased recruitment at or above the thermocline, in contrast to a previous mesocosm experiment with a stronger thermal gradient and a different population of larvae, suggesting that stratification intensity may affect depth of larval settlement and spat recruitment. Settlement rate did not appear to be a strict function of larval encounter rate with the spat collectors. Higher spat counts in treatments with a $1.5^{\circ} \mathrm{C}$ thermocline than in other turbulence treatments, even when results were corrected for differences in competency among the various treatments, suggest that thermal gradients have a potential commercial importance in both the collection and hatchery production of scallop spat.
\end{abstract}

KEY WORDS: Depth of larval settlement - Larval scallop behaviour - Mesocosm study $\cdot$ Placopecten magellanicus · Spat recruitment · Thermocline · Turbulence

\footnotetext{
- Contribution to the programs of OPEN IOcean Production Enhancement Network, one of the 15 Networks of Centres of Excellence supported by the Government of Canada) and GIROQ (Groupe Interuniversitaire de Recherches Océanographiques du Québec)

- Present address: Ross Island Salmon Ltd, PO Box 21, North Head, Grand Manan, New Brunswick E0G 2M0, Canada. E-mail: anderel@nbnet.nb.ca
}

\section{INTRODUCTION}

The vertical distribution of planktonic larvae of benthic marine invertebrates can be influenced both by active larval responses to environmental stimuli on a small scale and passive transport by water movements within the water column on meso and/or large scales. The degree to which these 2 mechanisms control larval 
vertical distribution will depend on the strength of vertical mixing-or degree of water column stratification-and the swimming ability of the larva (see review by Mileikovsky 1973). Many species of benthic invertebrates produce larvae which undertake vertical migrations at some point during their pelagic existence and a wide variety of environmental stimuli [both biological (e.g. food, predators, prey) and/or physical (e.g. gravity, light, pressure, salinity, temperature, tides)] are known to influence these larval vertical movements (see reviews by Thorson 1964, Crisp 1974, Sulkin 1984, Young \& Chia 1987). A large number of studies have shown how vertical discontinuities in physical factors such as salinity and temperature (i.e. haloclines and thermoclines, respectively) can influence the vertical distribution and movement of planktonic invertebrate larvae. Species from a wide variety of taxonomic groups including polychaetes, gastropods, bivalves, cirripedes, decapods, bryozoans, and echinoderms produce larvae whose vertical position in the water column has been shown to be influenced by vertical discontinuities in salinity and/or temperature (e.g. Harder 1968, Oshurkov et al. 1982, Scrope-Howe \& Jones 1986, Boudreau et al. 1991, 1992, Thiébaut et al. 1992, Raby et al. 1994, Gallager et al. 1996, Manuel et al. 1996b). Although the scientific literature on the vertical distribution of invertebrate planktonic larvae in the water column in relation to vertical boundaries and water column mixing is substantial, very little work has been conducted to examine how these factors influence settlement of larvae [but see Boudreau et al. (1992) who found that laboratory thermoclines significantly reduced the number of post-larval lobster Homarus americanus settling in comparison with control columns of water with no temperature discontinuities].

Very little is known about the settlement requirements of larvae of the giant or sea scallop Placopecten magellanicus (Gmelin). Only 3 laboratory studies to date have been published on the settlement preferences of this species. Culliney (1974) found that larvae settled on fragments of conspecific adult shells, glass shards, and small pebbles. Pearce \& Bourget (1996) tested a variety of artificial materials as settlement substrata (including onion bags, monofilaments, Astroturf, $\operatorname{Vexar}^{(3)}$ meshes, scallop shells, filter-wool) under hatchery-type conditions and found that polyester filter-wool was, by far, the best substratum for collecting settled spat. They also reported that microbial films enhanced larval settlement rate. Pearce et al. (1996) found that giant scallop larvae settled predominantly at or above a thermal gradient (i.e. $\sim 11^{\circ} \mathrm{C}$ established over a $1 \mathrm{~m}$ depth interval) created in $9 \mathrm{~m}$ deep mesocosms. Settlement rate on artificial (i.e. polyester filterwool) and natural (i.e. red filamentous alga Polysipho- nia lanosa) substrata were similar (Pearce et al. 1996). The scant information available on the settlement requirements of this species is surprising given its economic importance for the fishing industry in Atlantic Canada and the northeastern United States (Bourne 1964, Sinclair et al. 1985, Naidu 1991) and the recent interest in its aquacultural development (Couturier 1990, Dadswell \& Parsons 1991). The paucity of laboratory data on larval settlement of giant scallops may be due to a number of factors including: (1) the species has a relatively long larval developmental time of at least 28 to $50 \mathrm{~d}$ at $15^{\circ} \mathrm{C}$ (Culliney 1974, Naidu et al. 1989, Couturier 1990) and (2) the species is relatively difficult to rear through settlement as high mortality generally occurs during this period (Tremblay 1988, C. M. Pearce pers, obs.).

In the field, natural spat settlement of Placopecten magellanicus has been recorded on a variety of substrata including: navigation buoys (Merrill \& Posgay 1967. Naidu 1970, Merrill \& Edwards 1975), gravel and pebbles (Kenchington et al. 1991, Thouzeau et al. 1991), shells of adult P. magellanicus (Naidu 1970), mussel byssal threads (Merrill \& Edwards 1975), red macroalgae (Naidu 1970), bryozoans (Baird 1953, Caddy 1972, Merrill \& Edwards 1975), hydrozoans, amphipod tubes, and sand grains (Larsen \& Lee 1978). Various field studies have collected giant scallop spat on artificial substrata such as polyethylene sheets and monofilament (Naidu \& Scaplen 1979, Naidu et al. 1981, Naidu \& Cahill 1986, Robinson et al. 1992, Parsons et al. 1993, Pouliot et al. 1995). While some of these studies have examined collector design and compared the efficiency of various substrata in collecting spat (e.g. Naidu et al. 1981, Pouliot et al. 1995), little information is available on how physical factors in the water column affect larval settlement distribution. Robinson et al. (1992) reported that horizontal spatial patterns of giant scallop settlement reflected known oceanographic circulation within Passamaquoddy Bay, Canada, but no known scientific research has examined the direct effect of physical oceanographic conditions on depth of larval scallop settlement on artificial spat collectors.

Aggregation of larvae of Placopecten magellanicus at or above thermoclines/pycnoclines has been documented both in the field (Tremblay \& Sinclair 1988, 1990a) and in laboratory mesocosms (Gallager et al. 1996. Manuel et al. 1996b). In a previous study, Pearce et al. (1996) found that settlement of giant scallop larvae-spawned from adults collected from Newfoundland, Canada--in $9 \mathrm{~m}$ deep thermally stratified mesocosms (i.e. $-11^{\circ} \mathrm{C}$ thermocline at a depth of 4.0 to $5.0 \mathrm{~m}$ with temperatures of $16^{\circ} \mathrm{C}$ above and $5^{\circ} \mathrm{C}$ below the thermal gradient) was greatest in collectors at or above the thermocline. The authors hypothesized that depth 
of settlement of scallop larvae in the field may be affected by such processes as water column stratification and vertical mixing, but were uncertain as to how settling larvae might respond to weaker gradients of temperature or under conditions of turbulent mixing.

The present study follows the previous work of Pearce et al. (1996) and examines the effect of weaker thermoclines and turbulence on the depth of settlement of larvae produced from giant scallops collected from a population located on Georges Bank, Canada. The results are discussed considering the applications to field spat collection, natural recruitment, and hatchery production of giant scallops.

\section{MATERIALS AND METHODS}

Tower Tank parameters. The experiment was conducted from December 1992 to February 1993 in a cylindrical Tower Tank (depth: $10.5 \mathrm{~m}$; inner diameter: $3.7 \mathrm{~m}$; volume: $117 \mathrm{~m}^{3}$ ) located in the Life Sciences Centre of Dalhousie University. The tank is constructed of reinforced concrete and lined with multiple, sprayed coatings of polyvinyl chloride (PVC). It was filled with seawater passed through a sandbed filtering system which removed particles above $50 \mu \mathrm{m}$ in size (nominal). Polyethylene bags (length: $9.5 \mathrm{~m}$; diameter: $0.60 \mathrm{~m}$; thickness: $150 \mu \mathrm{m}$ ), filled with 26861 of $1 \mu \mathrm{m}$ cartridge-filtered seawater and suspended at the water surface using styrofoam floatation collars, were used to divide the tank into replicate columns of seawater (Fig. 1). Salinity of seawater in the tubes, at the time of filling, ranged from 30.4 to $30.6 \%$. While measurements were not conducted during the experiment, salinities would not be expected to vary substantially. Any slight increase in salinity due to surface evaporation, which was minimal, would have been compensated for by the addition of phytoplankton and periodically topping up tubes with $-30 \%$ seawater. Vertical profiles of oxygen concentration, conducted in previous static mesocosm experiments run in $9.0 \mathrm{~m}$ deep tubes, indicate that dissolved oxygen concentration remains relatively stable at 8.5 to $9.0 \mathrm{ppm}$ throughout a $50 \mathrm{~d}$ experimental period, indicating that there is no problem with static tubes turning anoxic.

A thermocline was established in the Tower Tank at a depth of 4.0 to $5.0 \mathrm{~m}$ by circulating chilled seawater $\left(\sim 4^{\circ} \mathrm{C}\right)$ through a titanium ring placed around the inner cir- cumference of the tank at a depth of $4.5 \mathrm{~m}$ and running hot freshwater $\left(-30^{\circ} \mathrm{C}\right)$ through a PVC ring set up at a depth of $4.0 \mathrm{~m}$ (Fig. 1). Actual thermal gradients in the experimental tubes varied with treatment manipulation (see 'Experimental protocol' section). Light was provided solely by an overhead array of three $1000 \mathrm{~W}$ phosphor-coated metal halide lamps set on a $12 \mathrm{~h}$ dark $12 \mathrm{~h}$ light photoperiod that were phase shifted so that 2 lights came on and switched off $\sim 30$ min before the other one. A gradual increase in light intensity during dark to light transition was afforded by the lamps' slow warm-up time. Light measurements taken a few

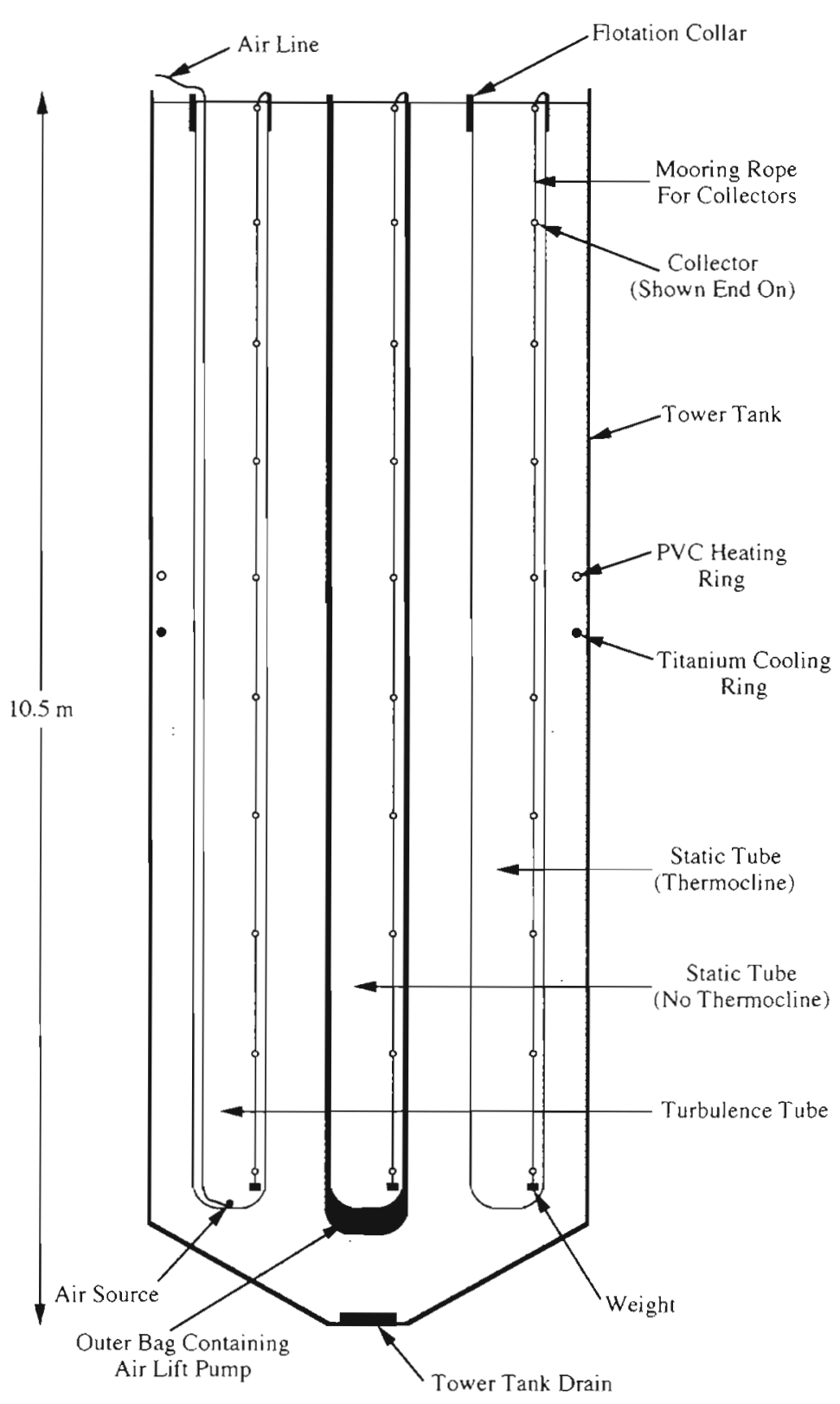

Fig. 1. Side view of Tower Tank, drawn to scale, showing set up of different treatment tubes 
centimetres above the water surface using a Weston Instruments Inc. model 756 illumination meter and a Gossen Lunasix 3 intensity meter showed light intensities ranging from $\sim 1800$ to 7000 lux or $\sim 15$ to $60 \%$ normal midday summer sun. Light intensity was greater in the center of the tank $(6026 \pm 701$ lux, mean \pm SD, $n=5)$ than around the perimeter $(3425 \pm 931$ lux, mean $\pm \mathrm{SD}, \mathrm{n}=20$ ).

Spawning and larval development. Adult giant scallops from a Georges Bank population were collected and maintained at an aquaculture site in suspended pearl nets at Mahone Bay, Nova Scotia for a period of at least $1 \mathrm{yr}$ prior to the experiment. Ripe individuals were transported to the laboratory in coolers and spawned the same day. Seven females and seven males were scrubbed clean and induced to spawn in $0.2 \mu \mathrm{m}$ filtered seawater by thermal stimulation and agitation of the water with a small submersible pump. The eggs from all females were mixed together and fertilized with a sample of mixed sperm of all 7 males. At $5.5 \mathrm{~h}$ post-fertilization, approximately 50 million developing embryos were added to the surface of a $9 \mathrm{~m}$ deep polyethylene tube in the Tower Tank, which was thermally stratified so that temperature in the top half of the tank was 15 to $16^{\circ} \mathrm{C}$ while that below the thermocline was 8 to $9^{\circ} \mathrm{C}$. The vertical distribution of the embryos was monitored during the next few days with the use of a profiling video camera (Polarized Larval Recorder, PLR; see Gallager et al. 1996). The embryos gradually sank, distributing themselves predominantly in the upper half of the water column; they were most dense in a region just above the thermocline. Four days after the addition of the embryos, large numbers of veligers were seen swimming at the surface of the tube, indicating developmental progression. At this time the tube was drained and the larvae collected on a $63 \mu \mathrm{m}$ Nitex ${ }^{\otimes}$ mesh. The larvae were rinsed into a $50 \mathrm{I}$ plastic bucket containing $\sim 351$ of 1 - $\mu$ m cartridge-filtered seawater at 15 to $16^{\circ} \mathrm{C}$ for counts of individuals. Approximately 540000 D-stage larvae were introduced into each replicate $9.5 \mathrm{~m}$ deep tube in the Tower Tank, giving a final larval concentration in each tube of $\sim 0.20$ larvae $\mathrm{ml}^{-1}$. This concentration is somewhat lower than typical hatchery larval rearing densities of 1 to 5 larvae $\mathrm{ml}^{-1}$ (Tremblay 1988), but at least 2 orders of magnitude greater than maximum densities found on Georges Bank [Tremblay \& Sinclair (1990a) reported peaks in larval concentration within the water column as high as 0.002 larvae $\mathrm{ml}^{-1}$ ]. While experimental larval concentration was markedly greater than natural densities, it represents approximately the lowest concentration at which workable numbers of spat can be collected under such conditions.

Cultured phytoplankton Isochrysis galbana (Tahitian variety: clone designation TISO) was added to the tubes to produce a concentration throughout the whole tube of $5.0 \times 10^{3}$ cells $\mathrm{ml}^{-1}$. The density of phytoplankton cells in the tubes was monitored during the course of the experiment with a multi-sizer Coulter Counter ${ }^{\circ}$ and additional TISO was added to maintain this density when needed (i.e. at larval ages 10,14, 22, and $30 \mathrm{~d}$ ). Phytoplankton was gravity fed throughout the length of each tube via the use of a vinyl sprinkler hose (inner diameter: $1.3 \mathrm{~cm}$ ) which ran the entire length of the tubes. This hose had small perforations every $2 \mathrm{~cm}$ of its length and distributed the phytoplankton evenly throughout the tube. This was confirmed by conducting Coulter counts on vertically stratified water samples.

Experimental protocol. Five different treatments, each with 3 replicate tubes, were established as follows: (1) no turbulence and a well-developed thermocline: 'Static Therm'; (2) no turbulence and no thermocline: 'Static'; (3) relatively low level of turbulence: 'Low Turb'; (4) medium level of turbulence: 'Med Turb'; and (5) relatively high level of turbulence: 'High Turb'. Distribution of the 15 tubes within the Tower Tank was completely randomized and their positions within the tank were constant throughout the duration of the experiment (Fig. 2).

Turbulence in the Low, Med, and High Turb tubes was created by pumping compressed air through a small, single-point orifice $(2 \mathrm{~mm}$ diameter capillary tube) positioned in the center at the bottom of each tube (Fig. 1). The position of the bubble stream rising up through the tubes was random (i.e. uncontrollable and not directed in any particular area of the tube). The different levels of turbulence were created by

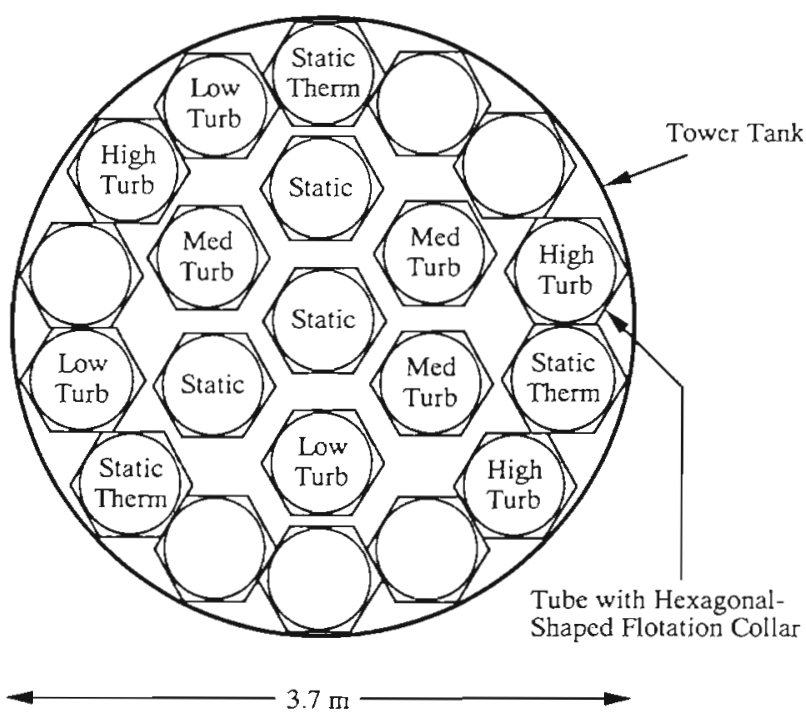

Fig. 2. Overhead view of Tower Tank, drawn to scale, showing position of treatment replicates. Tubes without treatment names were part of a separate experiment 
using different air pressures. Rates of turbulent energy dissipation $(\varepsilon)$ were calculated for each replicate tube using recorded profiles of the entire water column taken with the PLR combined with a modification of the theoretical approach of Dickey \& Mellor (1980). Particle images on the video tapes were integrated over $1 / 60 \mathrm{~s}$ to produce streaks. Streak lengths were proportional to the sum of the PLR profile speed and the speed of the particle movement. For each particle $i$ within a single video field $f$, the $x, y$, and $z$ components of the instantaneous velocity $\left(\mathrm{cm} \mathrm{s}^{-1}\right)$ were calculated - assuming isotropy in the horizontal diffusional field-as:

$$
\begin{aligned}
u_{i} & =\left[\left(x_{2}-x_{1}\right)-p\right] / t \\
v_{1} & =\left[\left(x_{2}-x_{1}\right)-p\right] / t \\
w_{i} & =\left[\left(z_{2}-z_{1}\right)-p\right] / t
\end{aligned}
$$

where $x_{1} z_{1}$ and $x_{2} z_{2}$ are the 2 -dimensional coordinates for the beginning and end of a streak, $p$ is the particle diameter, and $t$ is the time (1/60 s). Fluctuating components of the velocities for each particle were calculated as:

$$
\begin{aligned}
u_{i}^{\prime} & =u_{1}-U_{x} \\
v_{1}^{\prime} & =v_{i}-U_{y} \\
w^{\prime}{ }_{1} & =w_{i}-U_{z}
\end{aligned}
$$

where $U_{x}, U_{y,}$ and $U_{z}$ are the mean particle velocities in each direction of a given field:

$$
\begin{aligned}
& U_{x}=\sum u_{i} / N \\
& U_{y}=\sum V_{l} / N \\
& U_{z}=\sum w_{l} / N
\end{aligned}
$$

and $N$ is the number of particles in the field. For a given video field $f$, the average of the fluctuating components of the velocities was calculated as:

$$
\begin{aligned}
\sigma u_{f} & =\left[\Sigma\left(u^{\prime}{ }_{l}\right)^{2} / N\right]^{0.5} \\
\sigma v_{f} & =\left[\sum\left(v^{\prime}{ }_{i}\right)^{2} / N\right]^{0.5} \\
\sigma w_{l} & =\left[\Sigma\left(w^{\prime}{ }_{i}\right)^{2} / N\right]^{0.5}
\end{aligned}
$$

The 3-component turbulent velocity $Q$ was calculated for each field as:

$$
Q_{f}=\left[\left(\sigma u_{f}\right)^{2}+\left(\sigma v_{f}\right)^{2}+\left(\sigma W_{f}\right)^{2}\right]^{0.5}
$$

The vertical turbulent diffusion VTD $\left(\mathrm{cm}^{3} \mathrm{~s}^{-3}\right)$ is the cube of the turbulent velocity:

$$
\mathrm{VTD}=Q^{3}
$$

and the turbulent energy dissipation rate $\varepsilon\left(\mathrm{cm}^{2} \mathrm{~s}^{-3}\right)$ is:

$$
\varepsilon=\mathrm{dVTD} / \mathrm{d} z
$$

where $z$ is $0.6 \mathrm{~m}$, the width of a tube (i.e. largest eddy size is constrained to the width of a tube).

The PLR was profiled at $10 \mathrm{~cm} \mathrm{~s}^{-1}$ and data were recorded at 60 fields $s^{-1}$. Data on $\varepsilon$ values were calculated as $10-\mathrm{cm}$ averages for 60 individual fields. Mean $\varepsilon$ values $\left(\mathrm{cm}^{2} \mathrm{~s}^{-3}\right)$ reported in this paper are the vertical averages from surface to bottom of each replicate tube and are as follows: Static Therm $\left(7.1 \times 10^{-7}, 1.2 \times 10^{-6}\right.$, $\left.4.3 \times 10^{-6}\right)$, Static $\left(1.6 \times 10^{-6}, 2.0 \times 10^{-6}, 7.0 \times 10^{-6}\right)$, Low Turb $\left(9.4 \times 10^{-6}, 2.5 \times 10^{-5}, 2.9 \times 10^{-5}\right)$, Med Turb $(6.8 \times$ $\left.10^{-5}, 1.5 \times 10^{-4}, 2.3 \times 10^{-4}\right)$, and High Turb $\left(1.1 \times 10^{-3}\right.$, $\left.2.7 \times 10^{-3}, 4.4 \times 10^{-3}\right)$. Typical intensities of oceanic turbulence span several orders of magnitude: open ocean $10^{-6}$ to $10^{-2}$, shelf $10^{-3}$ to $10^{-2}$, coastal zone $10^{-3}$ to $10^{0}$, tidal front $10^{-1} \mathrm{~cm}^{2} \mathrm{~s}^{-3}$ (Kiørboe \& Saiz 1995). The turbulence intensities used in the present experiment, thus, ranged from open ocean (i.e. Static Therm, Static, Low Turb, Med Turb) to shelf or moderate coastal conditions (i.e. High Turb) and were typical of giant scallop larval habitats.

Temperatures within the tubes during the first $7 \mathrm{~d}$ of the experiment (i.e. larvae 4 to $11 \mathrm{~d}$ old) were somewhat variable as the thermal regimes were being established in the various treatments. During this period, temperatures were generally $12-13^{\circ} \mathrm{C}$ just below the water surface and gradually decreased to $9-10^{\circ} \mathrm{C}$ at the bottoms of the tubes (Fig. 3). An exception to this generalization was the High Turb treatment which was vertically homogeneous with respect to temperature (i.e. $11^{\circ} \mathrm{C}$ at all depths at $7 \mathrm{~d}$ old). By the time larvae were $12 \mathrm{~d}$ old, all treatments had developed their characteristic thermal structures. A $1.5^{\circ} \mathrm{C}$ thermocline was established in the Static Therm and Low Turb tubes at a depth of 4.0 to $5.0 \mathrm{~m}$ while the Static treatment remained unstratified. The latter treatment was created by housing the tube containing the larvae within another polyethylene bag and mixing seawater between the two using an air lift pump (Fig. 1). This procedure was sufficient to completely break down the thermocine within these tubes. A thermal gradient was established in the Med Turb tubes at a depth of 4.0 to $5.0 \mathrm{~m}$, but the temperature differential was only $\sim 0.5^{\circ} \mathrm{C}$ due to stronger vertical mixing. Higher rates of turbulence within the High Turb treatment produced unstratified conditions. The temperature in all the tubes gradually increased by $2{ }^{\circ} \mathrm{C}$ over the following week (Fig. 3) due to a gradual warming of the water column. This was most likely a result of surface heating by the overhead lights and transfer of this heat to depth by water column mixing in some of the tubes. To prevent temperatures in the upper part of the water column from becoming excessive for larval development, when larvae were $28 \mathrm{~d}$ old the flow rate in the chilling coil was increased. By larval age $48 \mathrm{~d}$, the temperatures had been brought back down to original levels. During these gradual shifts in temperature, the thermal gradients in the various treatments remained unchanged (Fig. 3).

Spat collectors were added to the tubes when larvae were $9 \mathrm{~d}$ old. A collector consisted of an open cylinder 
Temperature $\left({ }^{\circ} \mathrm{C}\right)$
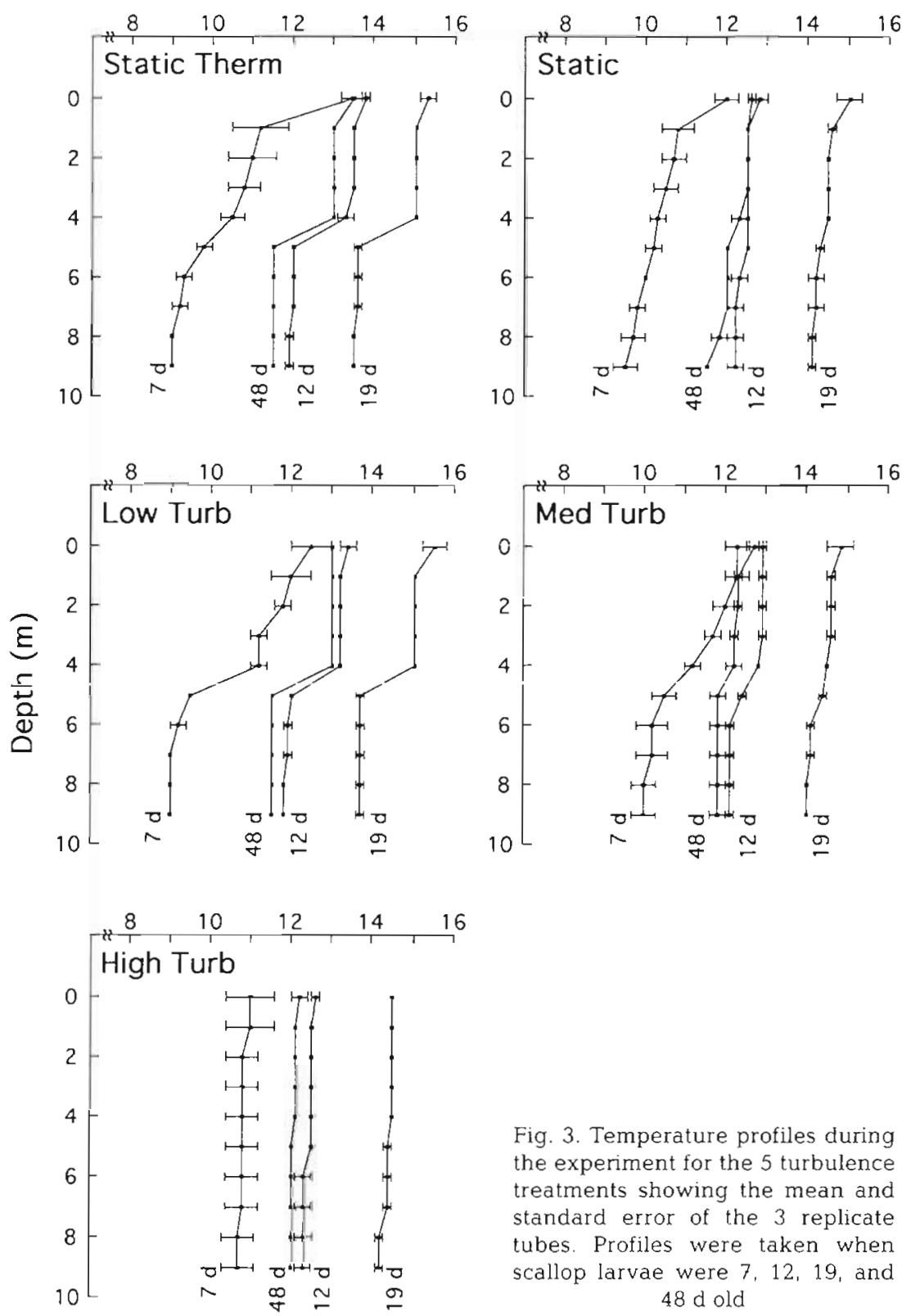

Fig. 3. Temperature profiles during the experiment for the 5 turbulence treatments showing the mean and standard error of the 3 replicate tubes. Profiles were taken when scallop larvae were $7,12,19$, and $48 \mathrm{~d}$ old

lectors and ropes were soaked in $0.2-\mu \mathrm{m}$ cartridge-filtered seawater for $12 \mathrm{~h}$ prior to deployment in the Tower Tank.

During the course of the experiment, the monofilament in some of the spat collectors was lost. The collectors were open-ended cylinders and, occasionally, protruding monofilament was snagged by the feeding tube or by the PLR. This occurred in the following turbulence treatment/depth combinations: Static 11 replicate at a depth of $2 \mathrm{~m}$ ), Low Turb (1 replicate at depths of 0,5 , and $7 \mathrm{~m}$ ), Med Turb (1 replicate at depths of 4 and $6 \mathrm{~m}$ and 2 replicates at a depth of $7 \mathrm{~m}$ ). and High Turb (1 replicate at depths of 4,7 , and $8 \mathrm{~m}$ ). The loose monofilaments were recovered, but counts from these were not included in the statistical analyses. Spat collected from the mesh tube itself, without monofilament, were counted and included in the analyses, however, since all of these tubes remained in place on their respective mooring ropes (i.e. $\mathrm{n}$ remained equal for all treatment combinations). A $t$-test comparing numbers of spat on collectors with and without monofilament at $7 \mathrm{~m}$ depth in the Low Turb, Med Turb, and High Turb treatments revealed no significant difference between the two $(p=0.4)$, suggesting that collectors with monofilament did not consistently collect more spat than those without.

When the larvae were $55 \mathrm{~d}$ old and very few planktonic individuals were evident in video profiles of

(length: $12 \mathrm{~cm}$; diameter: $4 \mathrm{~cm}$ ) of black, low-density, polyethylene mesh (Vexar ${ }^{\otimes}$ brand made by DuPont Canada Inc.; mesh size $3.8 \mathrm{~mm}$ ) stuffed with a tangle of $6 \mathrm{~m}$ of $0.40 \mathrm{~mm}$ diameter, aquamarine monofilament (12 lb or $5.5 \mathrm{~kg}$ test). Collectors were hung from a $5 \mathrm{~mm}$ diameter, yellow polypropylene rope which extended the length of each tube and was weighted at the bottom. One collector was placed at every metre interval starting just below the water surface and continuing down to $9 \mathrm{~m}$ (i.e. $0.5 \mathrm{~m}$ above the bottom of tube). One 'string' of collectors was hung in each replicate tube close to the tube wall (total of 150 collectors). All col- any of the tubes, the collectors were slowly and carefully pulled to the surface, removed from the rope, placed into separate specimen bags, and preserved with $70 \%$ ethanol. The polypropylene rope itself was carefully cut into $1 \mathrm{~m}$ lengths, bagged, and preserved with $70 \%$ ethanol as well. Just prior to counting, the collectors and ropes were soaked in a $1 \%$ bleach solu-

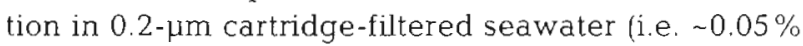
sodium hypochlorite) for at least $10 \mathrm{~min}$ to ensure that any remaining byssally attached spat were dislodged (Bourne et al. 1989, Heasman et al. 1994) and then rinsed with a jet of hot freshwater (5 1 in total) to 
remove all spat and larvae. Previous studies had shown that this technique removed all individuals from similar substrata (Pearce \& Bourget 1996, Pearce et al. 1996). The ethanol that the collectors and ropes were originally preserved in, the bleach that they were soaked in, and the freshwater rinsings were all passed through a $75 \mu \mathrm{m}$ Nitex ${ }^{\otimes}$ mesh to collect the spat and larvae. Counts of individuals were made with the use of a dissecting microscope set up for polarized light viewing as larvae and young juveniles of giant scallop are birefringent (see Gallager et al. 1989 for technique).

Individuals were counted as spat only if new dissoconch (i.e. post-metamorphic) shell growth was evident, otherwise they were classified as larvae. This type of classification is somewhat conservative in estimating numbers of spat present, since individuals which are in the process of metamorphosis, but have yet to lay down a visible layer of new shell growth, will be classified as larvae. Other indicative signs of scallop metamorphosis include the loss of the larval velum, the development of gill bars, and the repositioning of the foot, but these are all features that are often hard to distinguish in preserved individuals - especially samples treated with solutions of hypochlorite. Thus, the most definitive measure of successful larval metamorphosis is the production of new dissoconch.

At the end of the experiment the tubes were completely drained using a high speed electrical pump (Jacuzzi ${ }^{1}$ SP125, 3450 RPM; pump speed: $\sim 1071 \mathrm{~min}^{-1}$ ) and the contents of each tube were collected on screens. The tubes were drained down to a depth of $8.5 \mathrm{~m}$, filtering the water through a $100 \mu \mathrm{m}$ Nitex ${ }^{*}$ mesh (denoted as the 'water' sample). The bottom $1.5 \mathrm{~m}$ was filtered separately through Nitex ${ }^{\circledR}$ meshes varying in size from 60 to $100 \mu \mathrm{m}$ depending on the tube. This 'bottom' sample included rinsings of the bottom of the tubes with a jet of 1- $\mu$ m filtered seawater. Water and bottom samples were preserved separately in $1 \%$ buffered formalin. Shell lengths of a random allotment of larvae from both samples were later measured using the computer image-analysis system BioScan OPTIMAS ${ }^{\circledast}$ 4.02. Shell length was defined as the greatest distance measured from the anterior to the posterior end of the larval shell, approximately parallel to the larval hinge. These larval shell lengths were used to standardize for varying levels of competency across tubes (see 'Statistical analyses' section).

Statistical analyses. Slight non-normality (judged by normal probability plots) and significant heterogeneity of variances (Cochran's test: $\alpha<0.01$ ) were evident in the raw data of numbers of spat on the collectors and ropes. A log transformation $[\ln (x+1)]$ was sufficient to both normalize the data and reduce the heteroscedasticity to non-significant levels. Counts of spat were analysed with a mixed model nested analysis of variance which was constructed as follows:

$$
\mathrm{Y}_{1 j k l}=\mu+\mathrm{M}_{j}+\mathrm{D}_{j}+\mathrm{MD}_{l j}+\mathrm{T}(\mathrm{M})_{k(j)}+\varepsilon_{i j k j}
$$

where $M=$ effect of mixing or turbulence (fixed factor with 5 levels), $D=$ effect of depth (fixed factor with 10 levels for collectors and 9 levels for rope), and $\mathrm{T}=\mathrm{ef}-$ fect of tube (random factor with 3 levels nested within mixing factor).

Multiple comparisons among depths and turbulence treatments were made with Least Significant Difference (LSD) tests with $\alpha=0.05$ (Sokal \& Rohlf 1981). The relationship between transformed numbers of spat and depth was further examined through linear regression analysis.

Although the effect of depth could be examined directly by simply using the transformed counts of spat found on the collectors and ropes, analysis of the effect of turbulence was complicated by the fact that differential larval growth rates in the various treatments (S. M. Gallager pers. obs.) led to different proportions of competent larvae available for settlement at the end of the experiment. In order to standardize settlement rates for variations in the percentages of competent larvae among treatments, the proportion of larvae $\geq 230 \mu \mathrm{m}$ in shell length taken from the tubes at the end of the experiment was calculated for each replicate tube. To calculate this proportion, larvae collected from both water and bottom samples were combined (N.B. the original separation of the 2 samples was done because information on numbers of planktonic versus benthic larvae was required for another study). The active substrate-seeking phase of larval development, termed the pediveliger, where larvae alternate between periods of crawling and swimming and have the capacity for weak byssus attachment to substrata, generally does not occur until a larval shell length of 230 to $280 \mu \mathrm{m}$ has been attained (Culliney 1974, Naidu et al. 1989, Couturier 1990; but see also Pearce et al. 1996 who reported finding metamorphosed individuals slightly smaller than $230 \mu \mathrm{m}$ ). The proportion of larvae $\geq 230 \mu \mathrm{m}$ was used to estimate how many spat would have been present in the tubes if $100 \%$ of the individuals had been competent, thus standardizing across tubes and treatments. These standardized values were used in a nested ANOVA as described above. Slight non-normality (judged by normal probability plots) and significant heterogeneity of variances (Cochran's test: $\alpha<0.01$ ) were evident in these standardized values for both the collector and rope data. A log transformation $[\ln (x+1)]$ was, again, sufficient to both normalize the values and reduce the heteroscedasticity to non-significant levels in both data sets. Comparisons among turbulence treatments were made with LSD tests with $\alpha=0.05$. 
Table 1. Placopecten magellanicus. Analysis of variance tables for log-transformed raw (Raw) and standardized (Stand) numbers of scallop spat on (A) collectors and (B) ropes. N.B. Raw counts of spat were standardized among tubes by taking into consideration the proportion of competent larvae in each tube (see text for full explanation of procedure). $M=$ effect of mixing or turbulence (fixed factor with 5 levels), $D=$ effect of depth (fixed factor with 10 levels for collectors and 9 levels for rope), $T=$ effect of tube (random factor with 3 levels nested within mixing factor), $\mathrm{df}=$ degrees of freedom, SS = sum of squares, MS = mean square

\begin{tabular}{|c|c|c|c|c|c|c|c|c|c|c|}
\hline \multirow{2}{*}{ Source } & \multicolumn{2}{|c|}{$d f$} & \multicolumn{2}{|c|}{ SS } & \multicolumn{2}{|c|}{ MS } & \multicolumn{2}{|c|}{$F$-value } & \multicolumn{2}{|c|}{$p$-value } \\
\hline & Raw & Stand & Raw & Stand & Raw & Stand & Raw & Stand & Raw & Stand \\
\hline \multicolumn{11}{|c|}{ (A) Collectors } \\
\hline $\mathrm{M}$ & 4 & 4 & 152.21 & 153.94 & 38.05 & 38.49 & 8.31 & 7.35 & $\leq 0.005$ & $\leq 0.005$ \\
\hline D & 9 & 9 & 17.83 & 26.88 & 1.98 & 2.99 & 4.52 & 3.39 & $\leq 0.0001$ & $\leq 0.005$ \\
\hline$M \times D$ & 36 & 36 & 17.98 & 42.09 & 0.50 & 1.17 & 1.14 & 1.33 & $=0.30$ & $=0.14$ \\
\hline $\mathrm{T}(\mathrm{M})$ & 10 & 10 & 45.81 & 52.37 & 4.58 & 5.24 & 10.46 & 5.95 & $\leq 0.0001$ & $\leq 0.0001$ \\
\hline Residual & 90 & 90 & 39.40 & 79.19 & 0.44 & 0.88 & & & & \\
\hline \multicolumn{11}{|l|}{ (B) Ropes } \\
\hline M & 4 & 4 & 88.05 & 83.38 & 22.01 & 20.85 & 6.10 & 3.78 & $\leq 0.01$ & $=0.04$ \\
\hline $\mathrm{D}$ & 8 & 8 & 16.70 & 19.12 & 2.09 & 2.39 & 7.10 & 2.68 & $\leq 0.0001$ & $\leq 0.01$ \\
\hline$M \times D$ & 32 & 32 & 16.28 & 29.46 & 0.51 & 0.92 & 1.73 & 1.03 & $=0.03$ & $=0.44$ \\
\hline $\mathrm{T}(\mathrm{M})$ & 10 & 10 & 36.06 & 55.22 & 3.61 & 5.52 & 12.27 & 6.20 & $\leq 0.0001$ & $\leq 0.0001$ \\
\hline Rcsidual & 80 & 80 & 23.52 & 71.26 & 0.29 & 0.89 & & & & \\
\hline
\end{tabular}

One-way ANOVAs, followed by Tukey tests with $\alpha=$ 0.05 , were used to analyse the size of larvae in the various tubes, the proportion of competent larvae in the various treatments, and the number of planktonic larvae counted by the PLR in the various treatments. All data were verified for normality and homogeneity of variances using normal probability plots and Cochran's test with $\alpha<0.01$, respectively. All statistical analyses and graphing were carried out using either the SuperANOVA 1.11 (Abacus Concepts 1989) or the SYSTAT 5.2.1 (Wilkinson 1992) computer packages for the Macintosh computer.

\section{RESULTS}

\section{Effect of depth}

\section{Collectors}

A nested ANOVA on the log-transformed number of spat found on the collectors showed that the effect of depth was highly significant $(F=4.52$, df $=9,90, \mathrm{p} \leq$ 0.0001 ; Table 1A) and was not significantly dependent on the interaction with turbulence treatment $(F=1.14$, $\mathrm{df}=36,90, \mathrm{p}=0.30$; Table 1A). An LSD multiple comparisons test on data pooled across all turbulence treatments revealed an increase in spat numbers with increasing depth (Fig. 4). While the analysis of variance revealed a non-significant interaction between depth and turbulence treatment, changes in depth profiles of spat counts among turbulence levels were suggested when interaction results were examined. Numbers of spat generally increased with depth in the Static Therm, Static, and Low Turb treatments, whereas spat were more evenly dispersed across depths in the Med Turb tubes and randomly distributed in the High Turb tubes (Fig. 4). Coefficients of determination $\left(r^{2}\right)$ from individual regression analyses of spat numbers and depth within each turbulence treatment confirmed this trend; coefficients were greatest for Low Turb (0.538), Static Therm (0.180), and Static (0.110) treatments, lower for Med Turb tubes (0.058), and lower still for High Turb tubes (0.002) (Table 2). The slight peak in spat numbers in the $0 \mathrm{~m}$ deep collectors in the Static Therm treatment was the result of a relatively high spat count in the surface collector from one of the 3 replicate tubes. If this value is left out of the regression analysis, $r^{2}$ for the Static Therm treatment increases to 0.458 (Table 2).

\section{Ropes}

A nested ANOVA on the log-transformed number of spat found on the ropes showed that the effect of depth was, again, highly significant $(F=7.10, \mathrm{df}=8,80, \mathrm{p} \leq$ 0.0001 ; Table 1B). The interaction between depth and turbulence treatment was slightly significant ( $F=1.73$, $\mathrm{df}=32,80, \mathrm{p}=0.03$; Table $1 \mathrm{~B}$ ). Depth profiles of numbers of spat in the 5 turbulence treatments generally exhibited the same trends as shown for the collector data (Fig. 5). Spat numbers increased with depth in the Low Turb $\left(r^{2}=0.471\right)$ and Static Therm $\left(r^{2}=0.393\right)$ treatments, whereas spat were more evenly distributed among depths in the Med Turb $\left(\mathrm{r}^{2}=0.050\right)$ and High Turb $\left(\mathrm{r}^{2}=0.039\right)$ tubes (Table 2, Fig. 5). As with the collector data, there was a slight peak in numbers 

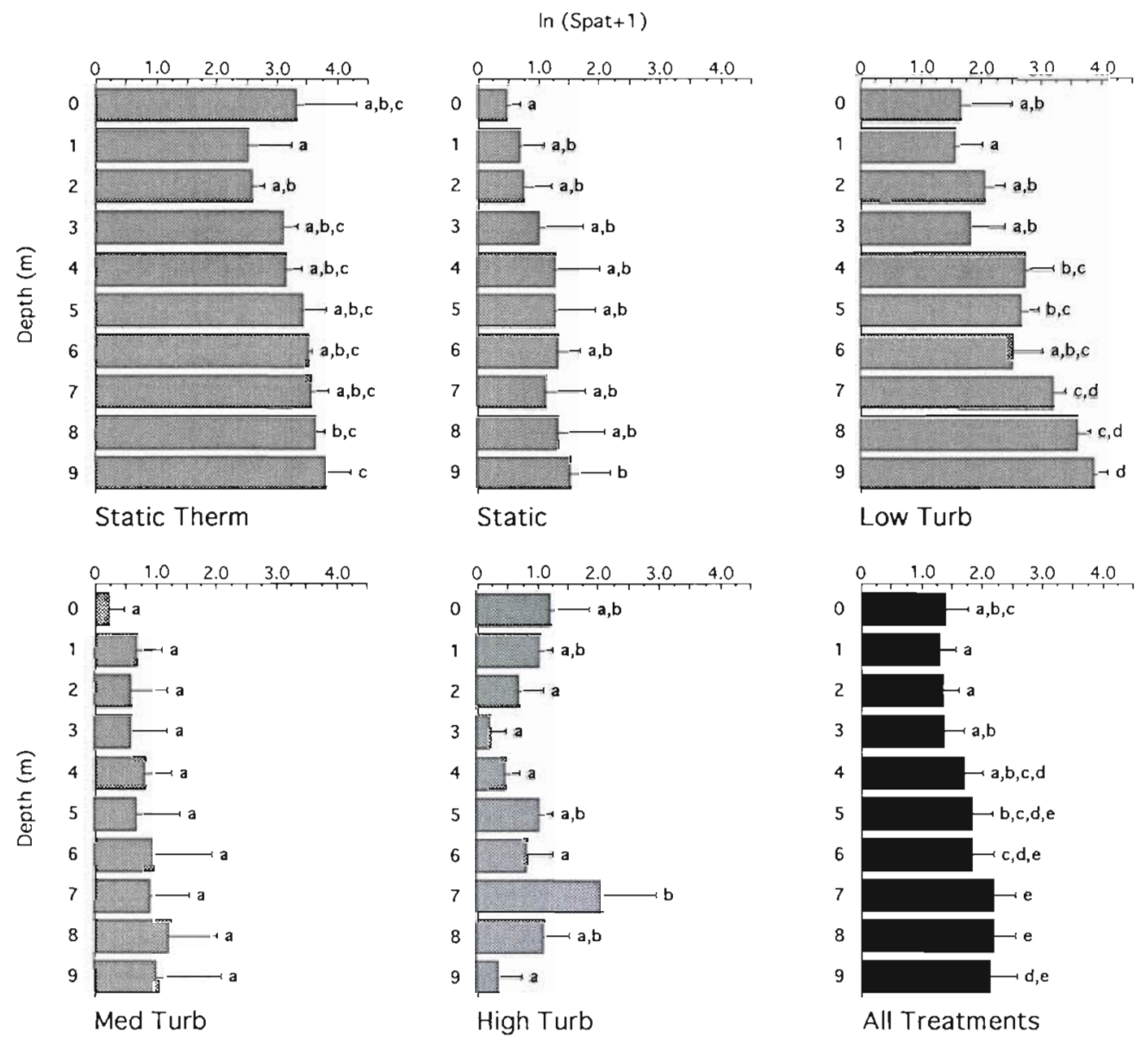

Fig. 4. Placopecten magellanicus. Depth profiles of log-transformed number of spat on collectors. Profiles are for the 5 separate turbulence treatments (i.e. Static Therm, Static, Low Turb, Med Turb, High Turb) as well as for the data pooled across all turbulence levels (i.e. All Treatments). Bars are the means of 3 (individual treatments) or 15 (all treatments) replicates and error bars are standard errors of the means. Letters by error bars represent the results of separate LSD tests examining the effect of depth within each turbulence treatment. Bars with the same letters within each profile are not significantly different (i.e. $\mathrm{p}>0.05$ )

of spat near the surface (i.e. $1 \mathrm{~m}$ deep rope portion) in the Static Therm treatment that was due to elevated spat counts in one of the 3 replicate tubes. If this value is left out of the regression analysis, $\mathrm{r}^{2}$ for the Static Therm treatment increases to 0.520 (Table 2). Two major differences between the rope and collector data should be noted. Firstly, the correlation between spat numbers and depth in the Static treatment is lower for the rope data set $\left(r^{2}=0.046\right.$; Table 2$)$ and there is no discernible increase in numbers of spat with depth on the ropes in this treatment (Fig. 5). Secondly, the collectors caught more spat than the ropes (compare Figs. 4 \& 5). An LSD multiple comparisons test on data pooled across all turbulence treatments in the rope data set (N.B. interaction effect was only slightly significant at $p=0.03$ ) shows an increase in numbers of spat with depth (Fig. 5).

\section{Effect of turbulence}

\section{Collectors}

The log-transformed number of spat on the collectors varied significantly with turbulence treatment $(F=8.31, \mathrm{df}=4,10, \mathrm{p} \leq 0.005$; Table $1 \mathrm{~A})$. As mentioned previously, there was no significant interaction between turbulence treatment and depth in the collector data set. An LSD multiple comparisons test on data pooled across all depths revealed that significantly more spat were collected in the Static Therm and Low Turb treatments than in the Static, Med Turb, and High Turb tubes, the latter 3 treatments not differing significantly from one another (Fig. 6). LSD tests on turbulence data at each depth showed the same general trend as with the pooled data 
Table 2. Placopecten magellanicus. Coefficients of determination $\left(r^{2}\right)$ and $p$-values for linear regressions of transformed numbers of spat on depth in each separate turbulence treatment for both the collector and rope data sets. Values of $r^{2}$ and $p$ in brackets listed in Static Therm treatment represent those resulting from a regression with 1 high value in the surface collectors/ropes deleted from the analysis

\begin{tabular}{lcc|}
\hline Treatment & $\mathrm{r}^{2}$ & $\mathrm{p}$-value \\
\hline Collectors & & \\
Static Therm & $0.180(0.458)$ & $\leq 0.05(\leq 0.0001)$ \\
Static & 0.110 & $=0.07$ \\
Low Turb & 0.538 & $\leq 0.0001$ \\
Med Turb & 0.058 & $=0.20$ \\
High Turb & 0.002 & $=0.83$ \\
Ropes & & \\
Static Therm & $0.393(0.520)$ & $\leq 0.0005(\leq 0.0001)$ \\
Static & 0.046 & $=0.28$ \\
Low Turb & 0.471 & $\leq 0.0001$ \\
Med Turb & 0.050 & $=0.26$ \\
High Turb & 0.039 & $=0.33$ \\
& & \\
\hline
\end{tabular}

(Fig. 6), as would be expected with a non-significant interaction term.

As mentioned in the 'Materials and methods', larvae grew at varying rates within the different turbulence treatments (S. M. Gallager pers, obs.) which resulted in differences in larval sizes at the end of the experiment. A 1 -way ANOVA on the untransformed larval size data revealed a highly significant effect of tube $(F=30.64$, $\mathrm{df}=14,1066, \mathrm{p} \leq 0.0001$ ) with a subsequent Tukey test showing a number of significantly different pairwise comparisons (Fig. 7). Larvae in 1 of the Static tubes and in all 3 of the High Turb tubes were significantly smaller than in any of the other mesocosms. None of the other tubes were significantly different from one another. This difference in growth rate led to varying proportions of competent larvae (i.e. $\geq 230 \mu \mathrm{m}$ shell length) among the turbulence treatments (1-way ANOVA on untransformed data: $F=5.10, \mathrm{df}=4,10, \mathrm{p} \leq$ 0.05; Fig. 8). The High Turb treatment had a smaller proportion of competent larvae than the 4 other treat-
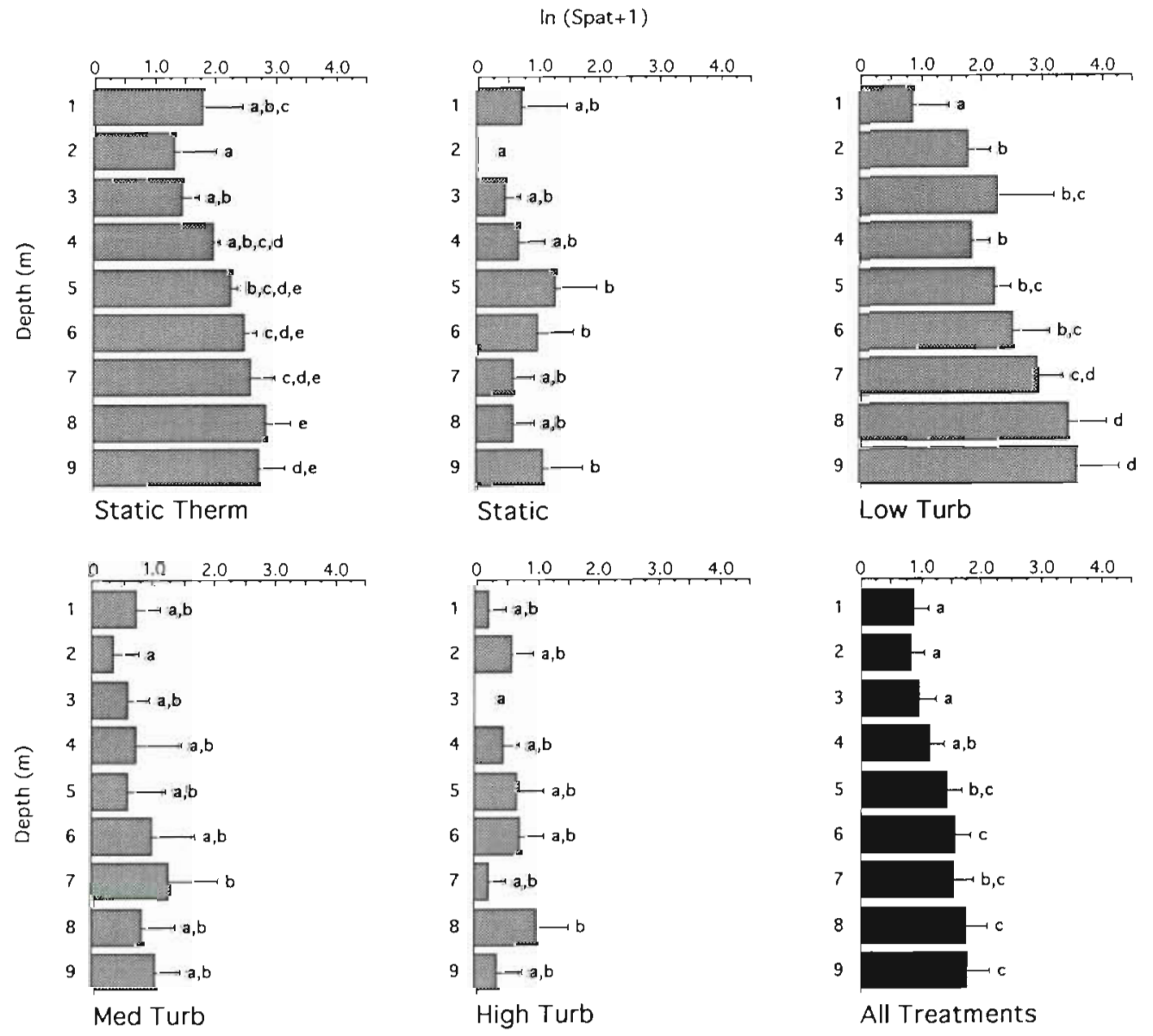

Fig. 5. Placopecten magellanicus. Depth profiles of log-transformed number of spat on ropes. Profiles are for the 5 separate turbulence treatments (i.e. Static Therm, Static, Low Turb, Med Turb, High Turb) as well as for the data pooled across all turbulence levels (i.e. All Treatments). Bars are the means of 3 (individual treatments) or 15 (all treatments) replicates and error bars are standard errors of the means. Letters by error bars represent the results of separate LSD tests examining the effect of depth within each turbulence treatment. Bars with the: same letters within each profile are not significantly different (i.e. $p>0.05$ ) 

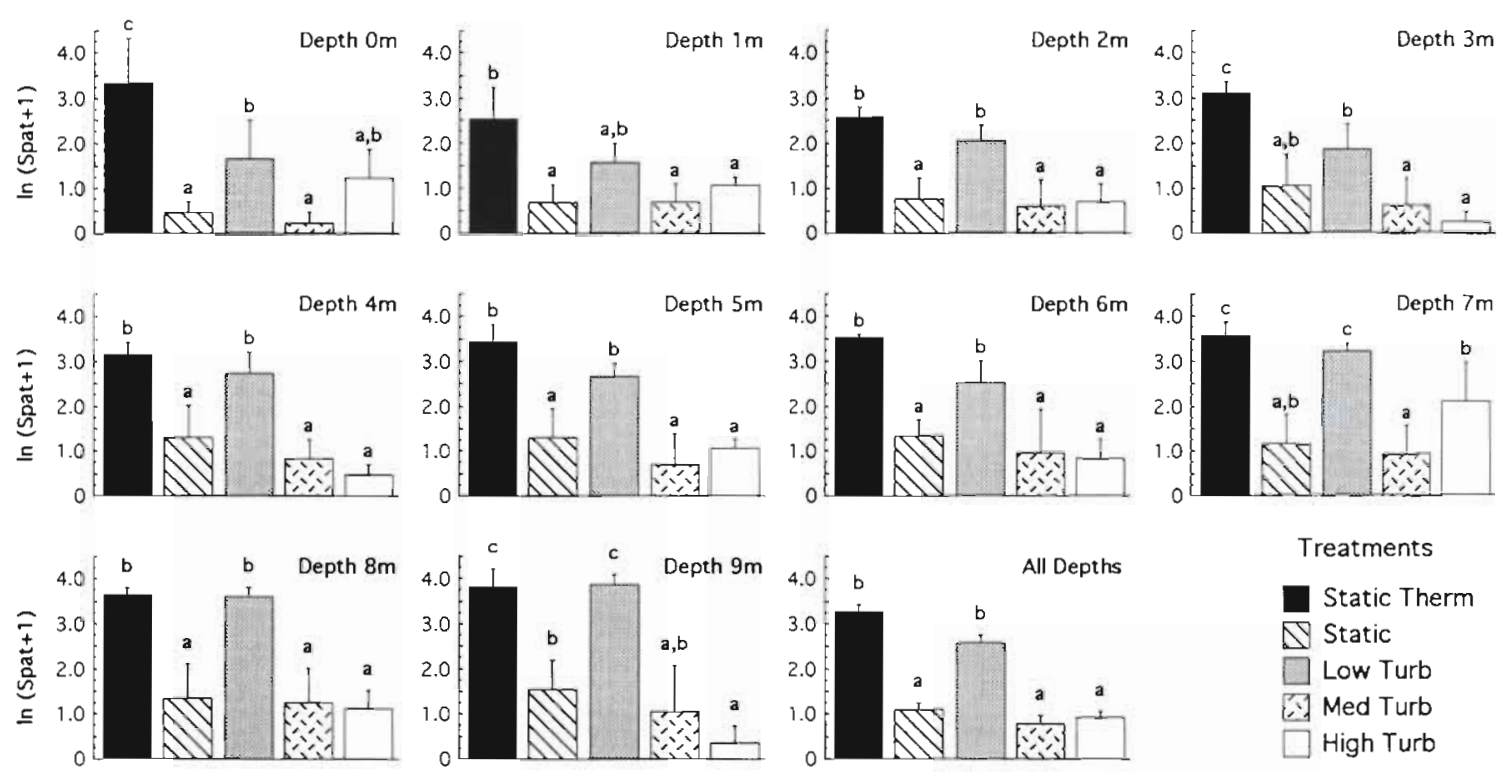

Treatments

Static Therm
$\triangle$ Static
Low Turb
$\therefore$ Med Turb
High Turb

Fig. 6. Placopecten magellanicus. Log-transformed number of spat on collectors in the 5 turbulence treatments at each depth. Data pooled across all depths is shown in the last graph labeled 'All Depths'. Bars are the means of 3 (individual depths) or 30 (all depths) replicates and error bars are standard errors of the means. Letters above error bars represent the results of separate LSD tests examining the effect of turbulence treatment within each depth (or depths pooled). Bars with the same letters within each graph are not significantly different (i.e. p >0.05)

ments - significantly smaller than the Low Turb and Med Turb treatments (Tukey analysis: $\mathrm{p} \leq 0.05$ ). No other pairwise comparisons were significantly different.

If the results in Fig. 6 are standardized for the varying proportions of competent larvae, we see only a slight change in the interpretation of the results. For spat on collectors, the effect of turbulence treatment remains highly significant $(F=7.35$, df $=$ 4, 10, p $\leq 0.005$; Table 1A) and not dependent on the interaction with depth $(F=1.33, \mathrm{df}=$ $36,90, p=0.14$; Table 1A). An LSD multiple comparisons test on the data pooled across all depths revealed only 1 change in pairwise comparisons from the unstandardized data: the High Turb treatment was no longer significantly different from the Low Turb treatment (Fig. 9A). All other pairwise comparisons remained the same as for the unstandardized spat counts.

\section{Ropes}

The log-transformed number of spat on the ropes also varied significantly with turbulence treatment $(F=6.10, \mathrm{df}=4,10, \mathrm{p} \leq 0.01$; Table 1B). As mentioned previously, there was a marginally significant interaction (i.e. $p=0.03$ ) between turbulence treatment and depth in the rope data set. LSD tests performed on turbulence data at each depth interval revealed, for the most part, a similar trend as seen with the collector data (Fig. 10). Significantly greater numbers of spat were collected in the Static Therm and Low Turb treatments than in the Static, Med Turb, and High Turb treatments at depths of $4,5,6,7,8$, and $9 \mathrm{~m}$. Greater numbers of spat were

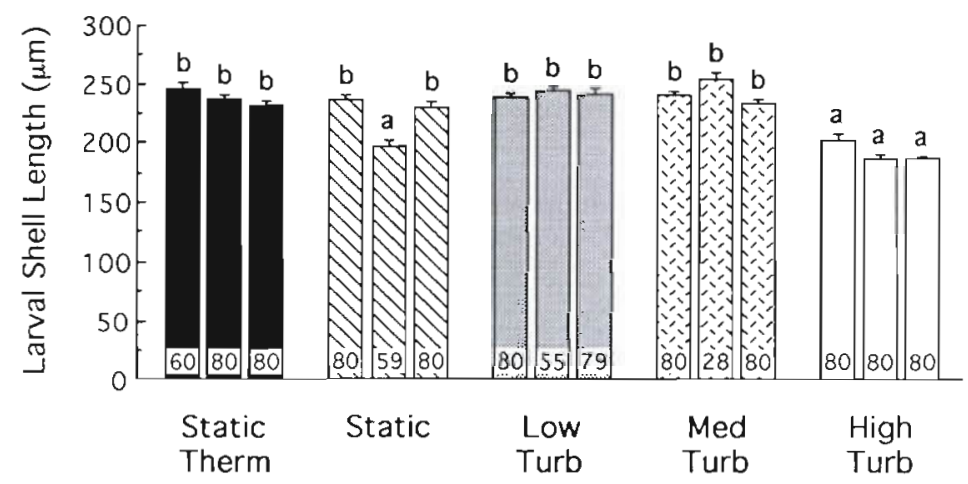

Fig. 7. Placopecten magellanicus. Shell lengths of larvae in each of the 3 replicate tubes of the 5 turbulence treatments. Bars are the means of 28 to 80 measurements (dependent on tube; see number at the bottom of each bar) and error bars are standard errors of the means. Letters above error bars represent the results of a Tukey test examining the effect of tube. Bars with the same letters are not significantly different (i.e. $\mathrm{p}>0.05$ ) 


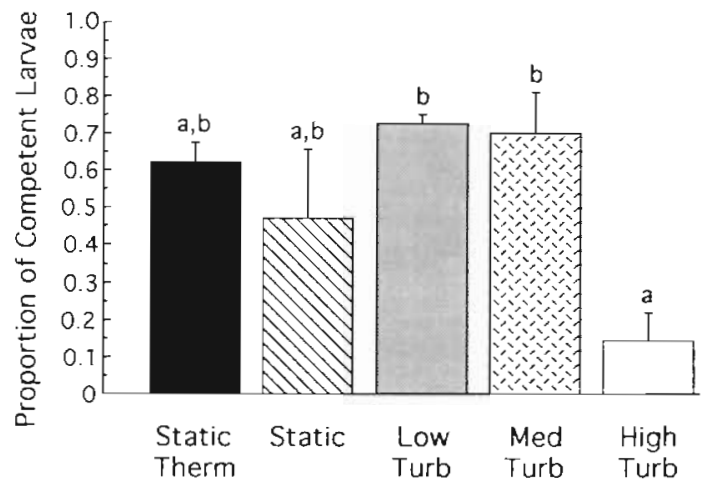

Fig. 8. Placopecten magellanicus. Proportion of larvae that were $\geq 230 \mu \mathrm{m}$ in shell length and deemed to be competent in the 5 turbulence treatments. Bars are the means of 3 replicates and error bars are standard errors of the means. Letters above error bars represent the results of a Tukey test examining the effect of turbulence treatment. Bars with the same letters are not significantly different (i.e. $p>0.05$ )

collected in the Static Therm and Low Turb treatments than in the other 3 treatments at depths of 2 and $3 \mathrm{~m}$, but the differences between Static Therm and High Turb at $2 \mathrm{~m}$ and Static Therm and Med Turb at $3 \mathrm{~m}$ were not significant. At a depth of $1 \mathrm{~m}$, Static Therm had significantly more spat than any of the other 4 treatments which did not differ significantly from one another. If the results are pooled across all depths, which could be justified with the marginally significant interaction term, the same pattern emerges - i.e. significantly greater numbers of spat collected in the Static Therm and Low Turb tubes than in the Static, Med Turb, and High Turb tubes with no significant differences between the former 2 treatments and the latter 3 treatments (Fig. 10).

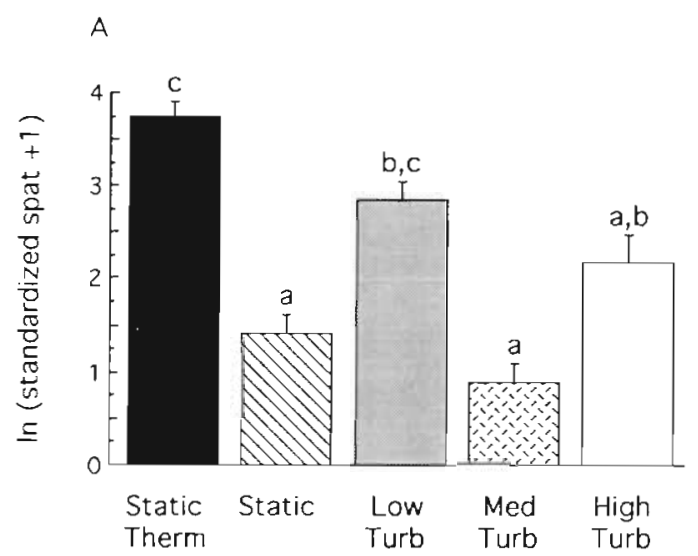

Standardizing spat counts on the ropes for varying proportions of competent larvae across turbulence treatments only changes the results slightly. The effect. of turbulence treatment is still significant $(F=3.78, \mathrm{df}=$ $4,10, p=0.04$; Table $1 B$ ), but the interaction between turbulence treatment and depth becomes non-significant $(F=1.03, \mathrm{df}=32,80, \mathrm{p}=0.44 ;$ Table 1B). An LSD multiple comparisons test on the standardized data pooled across all. depths revealed only 2 changes in pairwise comparisons from the unstandardized pooled data: the High Turb treatment was no longer significantly different from the Static Therm treatment or the Low Turb treatment (Fig. 9B). All other pairwise comparisons remained the same as for the unstandardized spat counts.

\section{DISCUSSION}

\section{Effect of vertical mixing on depth of larval settlement}

The depth distribution of spat on the collectors and ropes was a function of the intensity of vertical mixing or turbulence. Spat recruitment to collectors increased with increasing depth in the Static, Static Therm, and Low Turb treatments, but this trend became progressively disrupted as turbulence increased (i.e. spat were more evenly distributed with respect to depth in the Med Turb treatment and more randomly distributed in the High Turb treatment). In the collector data set, however, differences in spat depth distributions among the 5 different turbulence treatments were not sufficient to produce a significant depth/turbulence interaction in the nested analysis of variance (N.B. a slight increase in numbers of spat with collector depth was

B

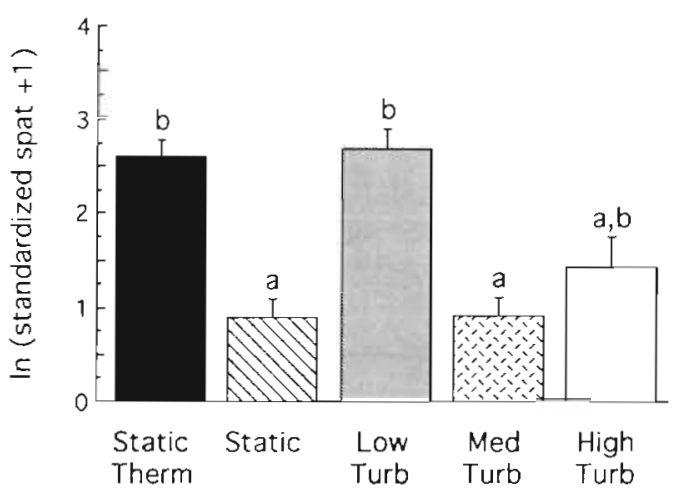

Fig. 9. Placopecten magellanicus. Log-transformed number of standardized spat (i.e. numbers of spat were standardized among treatments for differing levels of competency) on (A) collectors and (B) ropes in the 5 turbulence treatments. Bars are the means of 30 (A) or 27 (B) replicates and error bars are standard errors of the means. Letters above error bars represent the results of separate Tukey tests examining the effect of turbulence treatment within A and B. Bars with the same letters are not significantly different (1.e. $p>0.05$ ) 

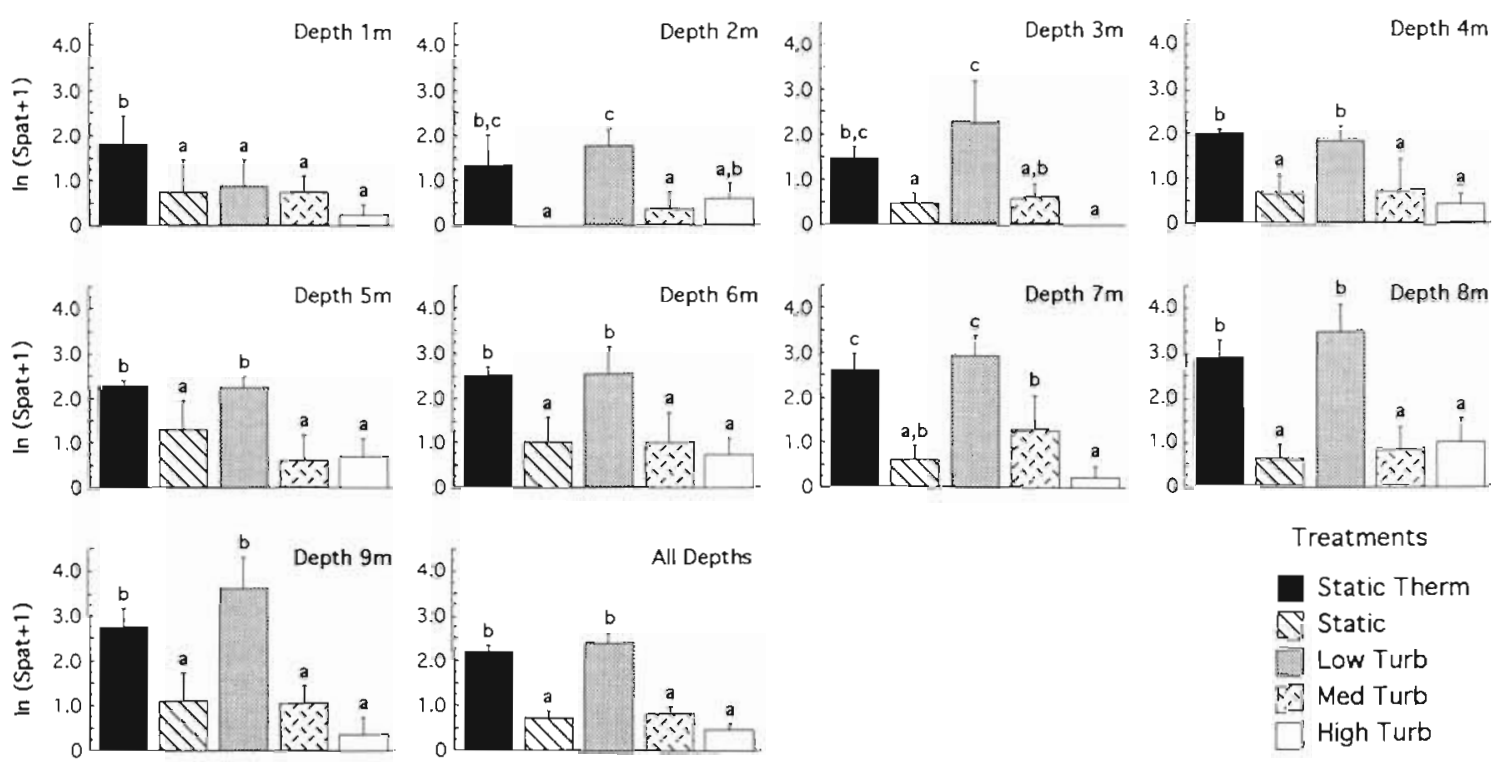

Treatments

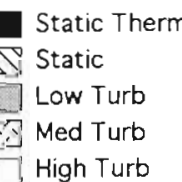

Fig. 10. Placopecten magellanicus. Log-transformed number of spat on ropes in the 5 turbulence treatments at each depth. Data pooled across all depths is shown in the last graph labeled 'All Depths'. Bars are the means of 3 (individual depths) or 27 (all depths) replicates and error bars are standard errors of the means. Letters above error bars represent the results of separate L.SD tests examining the effect of turbulence treatment within each depth (or depths pooled). Bars with the same letters within each graph are not significantly different (i.e. $p>0.05$ )

still evident in the Med Turb treatment even though there was no significant pairwise comparisons among depths and $\mathrm{r}^{2}$ was only 0.058; Fig. 4).

Similarly, spat recruitment on the mooring ropes increased with increasing depth in the Static Therm and Low Turb treatments, with progressive disruption of this trend as turbulence increased in the Med Turb and High Turb mesocosms. However, numbers of spat on the ropes in the Static treatment did not increase with depth as they did on the collectors. The reason for this is not entirely clear. Since collectors and ropes were hauled out of the water column at the end of the experiment, more spat were likely to be lost on the deeper collecting surfaces as these passed through the greatest length of water column and were exposed to the longest periods of physical agitation during the sampling procedure. Spat may have been more easily lost from the rope surfaces than the more heterogeneous collectors which were filled with a tangle of monofilament (N.B. although the mesh size of the collectors was not small enough to retain loose spat, the entanglement of monofilament would be expected to entrap dislodged individuals). If a trend of increasing spat recruitment with depth had been established on the ropes in the Static treatment, it probably would have been relatively weak (compare Static depth distribution with those in Static Therm and Low Turb treatments in the collector data set), and may have been disrupted by the sampling process. If deeper collecting surfaces did lose more spat than shallower sur- faces, then trends of increasing spat numbers with increasing depth will tend to be underestimated in all turbulence treatments in both data sets. The relatively weaker linear relationship of spat with depth in the Static treatments of both collector and rope data sets, as compared to the Static Therm and Low Turb treatments, may be due to lower numbers of recruiting spat (see 'Effect of turbulence on spat recruitment' section below).

\section{Factors controlling vertical spat distributions: evidence for larval behaviour and physical water-column mechanisms}

\section{Larval behaviour}

Field studies that have examined the recruitment of pectinids to artificial collectors placed at various depths in the water column have generally found that spat collection is greatest in mid-water (Brand et al. 1980, Hortle \& Cropp 1987, Sause et al. 1987. Sumpton et al. 1990, Margus 1991, Burnell et al. 1995) or closer to the sea floor (Mason 1969, Ventilla 1977, Buestel et al. 1979, Naidu \& Scaplen 1979, Wallace 1982, Fraser 1983, Ruiz-Verdugo \& Cáceres-Martínez 1991, Thouzeau 1991, Ambrose et al. 1992, Young et al. 1992, 1995, Harvey et al. 1993, Peña et al. 1995). Recruitment to collectors very close to the sea floor can be reduced, however, due to the effects of siltation (Naidu \& 
Scaplen 1979, Brand et al. 1980, Sumpton et al. 1990, Thouzeau 1991) and/or predation (Sumpton et al. 1990). Many hypotheses have been put forward to explain the relatively low recruitment to spat collectors in the upper water column, including: distribution and/or behaviour of the larvae, fouling of surface collectors by algae, the effects of turbulence and wave action near the surface (Brand et al. 1980), low salinity surface water (Margus 1991), and/or predation by recently settled predators such as starfish (Naidu \& Scaplen 1979). Results from the present study suggest that lower recruitment rates on the shallower collectors of the Static Therm, Static, and Low Turb treatments are most likely due to larval behaviour at settlement.

In waters off Newfoundland, Naidu \& Scaplen (1979) found that juvenile starfish Asterias vulgaris recruited predominantly to collectors in the upper water column and the authors attributed the lower numbers of giant scallop Placopecten magellanicus spat in these collectors to predation losses. In the present study, lower recruitment rates on the shallower collectors and ropes in the Static Therm, Static, and Low Turb treatments cannot be attributed to selective predation since no predators of giant scallop larvae or spat were present in the tubes. Margus (1991), who conducted field experiments in the Krka River estuary in Yugoslavia, proposed that the decrease in numbers of spat of the scallops Chlamys opercularis and $C$. varia in surface collectors was due to the strong influence of the Krka River which reduced the salinity of surface waters to below optimum levels for larval metamorphosis and juvenile survival. In our experiment, salinity was constant throughout the water column in all tubes and there was no salinity layering of water masses near the surface that may have affected settlement or recruitment patterns.

Brand et al. (1980) reported lower recruitment of the scallops Chlamys opercularis and Pecten maximus in surface collectors in the North Irish Sea and discussed the potential factors causing this distribution including: the effects of wave action and turbulence near the water surface, macroalgal fouling of near-surface collectors, and larval behaviour. Although not implicit, it was inferred that algal fouling, wave action, and turbulence in the upper water column would reduce recruitment to surface collectors by decreasing settlement rate and post-settlement survival (Brand et al. 1980). In the present experiment, an increase in spat numbers with depth was evident in tubes without turbulence (i.e. both Static treatments in the collector data set and the Static Therm treatment in the rope data set) indicating that relatively low recruitment to shallow collectors can occur even without surface turbulence. Macroalgal fouling of collectors was not a problem in this study, but some collectors and ropes developed a visible coating of microalgal slime consisting primarily, but not restricted to, pennate diatoms of the genera Nitzschia, Navicula, and Fragilaria. In the tubes where this film was present, it was usually on collectors and ropes in the upper water column. The depth distribution of these microalgae on the collectors and ropes increased with increasing turbulence (Table 3). It is unlikely, however, that this microalgal film was the primary factor reducing settlement in the upper water column since the trend of increasing spat numbers with increasing depth was clearly evident in the Static Therm treatment which had no visible microalgal film on any of the collectors or ropes (Table 3).

What is most plausible for the present study, then, is that larval behaviour at settlement was primarily responsible for the increase in recruitment with depth in the Static Therm, Static, and Low Turb treatments. Giant scallop larvae have been shown to undertake diel vertical migrations both in laboratory mesocosms (Silva-Serra \& O'Dor 1988, Silva-Serra 1995, Gallager et al. 1996, Manuel et al. 1996b) and in the field (Trem-

Table 3. Presence of microalgae on collectors and ropes in the 5 turbulence treatments (Static Therm ... High Turb) at each depth. The symbol "indicates the visible presence of a microalgal slime and the number of symbols indicates the number of replicates with this algal film. NA: not applicable

\begin{tabular}{|c|c|c|c|c|c|c|c|c|c|c|}
\hline \multirow{2}{*}{$\begin{array}{l}\text { Depth } \\
\text { (m) }\end{array}$} & \multicolumn{2}{|c|}{ Static Therm } & \multicolumn{2}{|c|}{ Static } & \multicolumn{2}{|c|}{ Low Turb } & \multicolumn{2}{|c|}{ Med Turb } & \multicolumn{2}{|c|}{ High Turb } \\
\hline & Collector & Rope & Collector & Rope & Collector & Rope & Collector & Rope & Collector & Rope \\
\hline 0 & & NA & - & NA & - & NA & $\cdots$ & NA & $\cdots$ & NA \\
\hline 1 & & & - & & - & & $\cdot$ & $\cdot$ & $\cdots$ & $\cdots$ \\
\hline 2 & & & & & $\cdot$ & & $\cdot$ & & $\cdots$ & $\cdots$ \\
\hline 3 & & & & & & & $\cdot$ & & $\cdots$ & $\cdots$ \\
\hline 4 & & & & & & & & . & $\cdots$ & $\cdots$ \\
\hline 5 & & & & & & & & . & $\cdots$ & $\cdots$ \\
\hline 6 & & & & & & & & & -. & $\cdots$ \\
\hline 7 & & & & & & & & & $\cdot$ & $\ldots$ \\
\hline 8 & & & & & & & & & $\cdots$ & $\cdots$ \\
\hline 9 & & & & & & & & & $\cdot$ & $\because$ \\
\hline
\end{tabular}


blay $\&$ Sinclair 1990b), indicating that depth regulation can be behaviourally controlled. Like many other larval invertebrates, giant scallop larvae are generally distributed lower in the water column as they approach competency (Culliney 1974, Gallager et al. 1996)-a behaviour probably associated with a substratumsearching phase as the larvae attain metamorphic competency. Greater larval abundance with depth, as competency approaches, has been demonstrated in other species of pectinids as well, including Patinopecten yessoensis (Maru et al. 1973) and Pecten maximus (Cragg 1980, Mason 1983), and may be associated with larval behaviours such as positive geotaxis and/or negative photokinesis (Kaartvedt et al. 1987, Gallager et al. 1996). Two other pieces of evidence suggest that larval settlement depth may be determined by active larval choice under conditions of limited vertical mixing. Firstly, under static mesocosm conditions, competent giant scallop larvae can vertically migrate and are not limited to a strictly benthic existence (Manuel 1996). Secondly, settlement depth can be affected by sufficiently strong vertical stratification and spat numbers may not increase positively with depth under such conditions (Pearce et al. 1996). Although giant scallop larvae are negatively buoyant and will sink if ciliary beating is arrested, a trend of increasing spat numbers with increasing depth may not be simply a function of larvae passively sinking to the bottom and being unable to choose among depths.

\section{Vertical mixing}

While depth of larval settlement and spat recruitment may be determined by larval behaviour under static or low turbulence conditions (i.e. $\varepsilon \leq 10^{-7}$ to $10^{-5} \mathrm{~cm}^{2} \mathrm{~s}^{-3}$ ), it also appears to be affected by physical processes such as vertical mixing at higher levels of turbulence (i.e. $\varepsilon \geq 10^{-4}$ to $10^{-3} \mathrm{~cm}^{2} \mathrm{~s}^{-3}$ ). Spat in the Med Turb and High Turb treatments were more evenly or randomly distributed with depth than in the static or low turbulence treatments, suggesting that competent larvae may have been suspended in the water column, forcing settlement to occur at depths that larvae may not have actively chosen under less turbulent conditions. Although competent giant scallop larvae can delay metamorphosis for at least 1 mo (Culliney 1974), and could potentially choose not to settle on shallower collectors, prolonged periods of vertical mixing and suspension of larvae will force individuals that can no longer delay metamorphosis to settle at their given depth provided an appropriate settlement surface exists. It is not known what may happen to suspended scallop larvae that can no longer delay metamorphosis and that do not contact a suitable settlement substra- tum. They may spontaneously metamorphose in the water column or perish. In the field, spat recruitment to near-surface collectors under suitably intense conditions of vertical mixing - where larvae are suspended in the upper water column-may be reduced due to factors discussed previously such as fouling of surface collectors by macroalgae, effects of turbulence and wave action near the surface, low salinity surface water, and/or predation by recently settled predators such as starfish.

Very little field research has examined the effects of vertical mixing on depth of larval scallop settlement, but what little information is available suggests that vertical mixing can, indeed, affect spat depth distributions. Ruzzante \& Zaixso (1985), for instance, suggested that the lack of an optimum settlement depth of Chlamys tehuelchus on artificial collectors in the San José Gulf, Argentina, may have been due to variable conditions in the water column such as high tidal range and shallow depths. In Bass Strait, Australia, Young et al. (1992) found that Pecten fumatus showed a trend of greater settlement in deeper spat bags early in the settling season, but noted that this trend became much more variable later in the settlement period. This change in spat depth distribution as the settlement season progressed may have been linked to changes in hydrographic conditions within the water column, although the authors did not test this hypothesis. The highest intensity of turbulence used in the present experiment $\left(-10^{-3} \mathrm{~cm}^{2} \mathrm{~s}^{-3}\right)$ is representative of weaker intensities found in coastal and shelf regions, but is 2 to 3 orders of magnitude lower than those that can typically occur in high energy zones such as fronts. In such areas of extreme, prolonged vertical mixing, larval settlement may be expected to be relatively random with respect to depth.

\section{Vertical stratification}

As noted previously, strong vertical stratification can also influence the depth of larval scallop settlement. In a subsequent Tower Tank experiment, giant scallop larvae, spawned from Georges Bank stock, settled primarily above a $5^{\circ} \mathrm{C}$ thermocline established at a depth of 5 to $6 \mathrm{~m}$ in $9 \mathrm{~m}$ deep mesocosms (Pearce 1996). Similarly, larvae spawned from a Newfoundland population settled predominantly at or above an $11^{\circ} \mathrm{C}$ thermocline established at a depth of 4 to $5 \mathrm{~m}$ in $9 \mathrm{~m}$ deep mesocosms (Pearce et al. 1996). It has been hypothesized that larval settlement may be enhanced in areas where vertical discontinuities or fronts intersect with the sea floor and that recruitment in such habitats would be beneficial due to elevated food levels and/or temperatures resulting in increased post-settlement 
growth rates (Pearce et al. 1996). Field evidence for such recruitment patterns was presented by Walossek (1991) who found large aggregations of Chlamys patagonica on the Argentinean shelf in a zone coinciding with the boundary of the summer thermocline, a region characterized by high productivity.

In the present study, there was no indication of increased settlement of Georges Bank larvae at or above the 0.5 to $1.5^{\circ} \mathrm{C}$ thermoclines established in the Med Turb, Low Turb, or Static Therm treatments (Figs. 4 \& 5), suggesting that a critical level of stratification intensity must be achieved before larvae begin to settle at or above a vertical discontinuity. Results from several Tower Tank studies suggest that, for a strict thermal gradient in a $9 \mathrm{~m}$ deep water column, this critical threshold of temperature stratification would be $>1.5^{\circ} \mathrm{C} \mathrm{m}^{-1}$, but $\leqslant 5.0^{\circ} \mathrm{C} \mathrm{m}^{-1}$ for Georges Bank larvae. It is unknown whether giant scallop larvae react to temperature per se or to other physical properties which change with variations in temperature such as density and viscosity (see discussions in Gallager et al. 1996, Manuel 1996). Also unknown is the effect of haloclunes on the planktonic distribution of larval giant scallops. Salinity gradients have been shown to affect the vertical distribution of larvae of other species of bivalves (Carriker 1951, Feeny 1984, Mann et al. 1991.) and it is plausible that giant scallop larvae are affected by an interaction of temperature and salinity and/or the associated changes in density and/or viscosity. Critical thresholds of thermal stratification may be lower than predicted if larvae react to changes in salinity, density, and/or viscosity rather than temperature alone. Further research is required in order to determine what physical variables giant scallop larvae are affected by and the response of larvae to combined salinity/temperature gradients.

Critical thresholds of vertical stratification at which larvae settle at or above the discontinuity may also be lower in a deeper water column. For instance, Tremblay \& Sinclair (1988) found that in the Bay of Fundy, New Brunswick, Canada, peaks in larval giant scallop concentration were associated with thermoclines with temperature differences of only 1.0 to $2.5^{\circ} \mathrm{C}$ over a vertical distance of $20 \mathrm{~m}$ or a temperature gradient of only 0.050 to $0.125^{\circ} \mathrm{C} \mathrm{m}^{-1}$ (N.B. the authors did not measure changes in salinity or density). In our $9.5 \mathrm{~m}$ deep Tower Tank studies, giant scallop larvae from Georges Bank have been found to aggregate at thermoclines as small as $0.8^{\circ} \mathrm{C} \mathrm{m}^{-1}$, but do not appear responsive to gradients less than this (Manuel 1996). That pelagic larvae are affected by thermal gradients of $1.5^{\circ} \mathrm{C}$ while settling larvae are not suggests an ontogenetic shift in gradient sensitivity and/or behavioural response.

In addition, there is also the possibility that critical thresholds may be dependent on larval population.
Larvae from Georges Bank, Passamaquoddy Bay (New Brunswick), and Mahone Bay (Nova Scotia) show dissimilarities in their vertical migration behaviour in laboratory mesocosms (Manuel et al. 1996b) which may be linked to genetic differences (Manuel et al. 1996a). While larvae from these 3 populations show similar settlement depth distributions in $9.5 \mathrm{~m}$ deep mesocosms with a $1.5^{\circ} \mathrm{C}$ thermocline established at a depth of 4 to $5 \mathrm{~m}$ (i.e. increase in settlement with depth with no peak at the thermocline; Pearce 1996), the possibility that differences in critical thresholds exist among the 3 populations cannot be entirely discounted.

For field collection of scallop spat in areas of relatively high stratification, Pearce et al. (1996) concluded that it may be most beneficial to place spat collectors within or around the layer of discontinuity instead of nearer the sea floor where settlement might be assumed to be greater, based on the general behaviour of competent larvae. The present study suggests that the degree of stratification will have an effect on the depth of settlement and that depth of placement of spat bags in the water column should take into account stratification intensity and vertical mixing. If stratification intensity is high, maximum recruitment may be expected at or above the discontinuity. However, under conditions of weak stratification and limited vertical mixing, spat collection should be greatest nearer the sea floor. In areas of intense turbulence spat may be collected throughout the water column if mixing conditions are prolonged or preferentially in deeper collectors if mixing is intermittent. Differences in published accounts of pectinid settlement depth (i.e. mid-water versus closer to the sea floor; see previous references) could be, at least partially, due to variations in water-column stratification intensity.

It should be noted that conditions on Georges Bank do exist where thermal stratification could influence depth of larval settlement. Tremblay \& Sinclair (1990a) measured vertical stratification intensities at various locations in the northeastern portion of the bank in October 1986 and 1987, when planktonic scallop larvae were present, and found some frontal zone areas where temperature dropped by as much as $5^{\circ} \mathrm{C}$ (from 12.5 to $7.5^{\circ} \mathrm{C}$ ) in the upper $40 \mathrm{~m}$ of the water column.

\section{Effect of turbulence on spat recruitment}

The number of spat found on both the collectors and ropes was significantly greater in the Static Therm and Low Turb tubes than in the Static, Med Turb, or High Turb treatments when results were not standardized for varying levels of competency among tubes. However, larvae grew at varying rates, dependent on the 
turbulence treatment, and this led to differing levels of competency among the tubes. Only 27.5, 13.8, and $2.5 \%$ of the larvae measured at the end of the experiment from the 3 replicate tubes of the High Turb treatment were deemed to be competent (i.e. $\geq 230 \mu \mathrm{m}$ shell length). This was in sharp contrast to most other tubes in the other turbulence treatments that had from 50 to $70 \%$ competency (N.B. one replicate tube of the Static treatment was an exception with only $11.9 \%$ larvae $\geq 230 \mu \mathrm{m}$ in shell length). Adjusting spat numbers for varying levels of larval competency among the tubes had a slight effect on the overall comparisons among turbulence treatments. The Static Therm and Low Turb treatments still remained greater than the Static, Med Turb, and High Turb treatments, but pairwise comparisons between Low Turb and High Turb in both data sets and Static Therm and High Turb in the rope data set became non-significant when results were standardized for competency differences. These results suggest that settlement rate may not be a simple function of larval encounter rate with the collectors as more spat were collected in the Static Therm tubes than in the Med or High Turb treatments.

It is interesting to note that the number of recruited spat was greatest in the treatments with the strongest thermoclines (i.e. Static Therm and Low Turb). This treatment effect could be due to several factors, working alone or in combination, including: (1) reduction of larval settlement and/or post-settlement survival in higher turbulence treatments as a result of negative effects of microalgal films, (2) differences in larval growth rates among the various turbulence treatments, (3) increased spat dislodgment with increased turbulence, and/or (4) increased larval survivorship due to thermal gradients in stratified treatments. Since visible films of microalgae were most developed on collectors and ropes in the Med Turb and High Turb tubes (Table 3), lower spat recruitment in those treatments could have been due to potential negative effects of these films leading to lower rates of larval settlement and/or increased post-settlement mortality. Inhibition of larval settlement by certain strains of bacteria has been shown for the bay scallop Argopecten irradians (Xu et al. 1991), but no research has been conducted with Placopecten magellanicus on settlement inhibition by biofilms. Since the diatom film was equally well developed in both the Static and Low Turb treatments, but the latter collected more spat than the former, microalgal filming of settlement substrata cannot be the sole factor responsible for the differences in spat recruitment among the turbulence treatments.

The low spat recruitment in the High Turb treatment was, at least partially, due to reduced larval growth. At the end of the experiment only High Turb tubes had planktonic larvae (albeit very few) still evident in video profiles of the water column. Veligers in the High Turb tubes were significantly smaller than those in the other turbulence treatments leading to a smaller percentage of larvae being competent to metamorphose. Standardizing for larval competency among the turbulence treatments increased potential spat numbers in the High Turb tubes and reduced the pairwise differences between Static Therm and High Turb as well as Low Turb and High Turb treatments (compare Figs. 6 \& 10 with Fig. 9). However, even with using standardized spat values, the High Turb tubes still had fewer potential recruited spat than the Static Therm and Low Turb treatments in both the collector and rope data setssignificantly fewer when compared with the Static Therm treatment in the collector data set. It should be noted that spat recruitment in the High Turb treatment may have been greater if the experiment had been continued to allow all larvae in these tubes to settle, although the probability of survival through metamorphosis of slow-growing veligers, as compared to fastergrowing individuals, is not known. In the field, however, a prolonged planktonic developmental period would most likely lead to reduced recruitment rates as a result of greater larval losses due to predation and potential advection away from suitable settlement sites. Thus, it might be expected that recruitment of larvae entrained in highly turbulent areas such as upwelling and downwelling zones, mixing fronts, and coastal mixing zones would be reduced in comparison to that of larvae undergoing development in stratified, calmer waters. Reduced larval growth rate may also be partially responsible for lower spat recruitment in the Static treatment as one of the Static tubes had significantly smaller larvae than those in the Static Therm, Low Turb, and Med Turb treatments. Possible reasons for differences in larval growth rates among the replicate Static tubes are not evident, but must be linked with some tube effect. Interestingly, larvae grew best in the Med Turb treatment (S. M. Gallager pers. obs.) indicating that differences in larval growth rate can only partially explain differences in spat recruitment among the various turbulence treatments.

Brand et al. (1980) suggested that reduced spat recruitment of the scallops Chlamys opercularis and Pecten maximus in surface spat collectors in the field may have been a result of increased turbulence near the surface which may have reduced post-settlement survival. In the present experiment, spat could have been dislodged from collectors and ropes by the bubbling action in the turbulence treatments. Obviously, the intensity of turbulence in the Low Turb tubes was not sufficient to significantly impact on recruitment in this manner, but turbulence intensities in the Med Turb and High Turb tubes may have been great enough to dislodge settled individuals. However, the 
relatively low rate of recruitment in the Static treatment, which was not subjected to mixing, suggests that dislodging of settled spat by turbulence was not the sole factor responsible for differences in spat recruitment among the turbulence treatments.

Thermoclines may increase larval survivorshipand, hence, numbers of competent larvae available for settlement-by creating a barrier between the larvae and the bottom of the tubes, which may be a rather inhospitable environment for veligers due to accumulations of debris, detritus, bacteria, and protozoans. Young larvae in the Static Therm and Low Turb tubes were predominantly distributed above the thermal gradient and undertook diel vertical migrations between the surface and thermocline. Larvae in the Static treatment, however, were scattered throughout the water column during daylight hours and concentrated near the surface at night, while larvae in the Med Turb treatment were distributed throughout the water column during both day and night (S. M. Gallager pers. obs.). Thus, veligers in the Static Therm and Low Turb treatments remained out of the debris, detritus, bacteria, and protozoans that may have accumulated at the bottom of the tubes while those in the Static and Med Turb treatments made excursions, or were mixed, into this potentially deleterious bottom environment. Exposure to these detrimental conditions most likely reduced Iarval survivorship in the Static and Med Turb treatments and, thus, total larvae available for settlement.

Counts of 28-and 29-d-old planktonic larvae taken throughout the water column in each replicate tube of

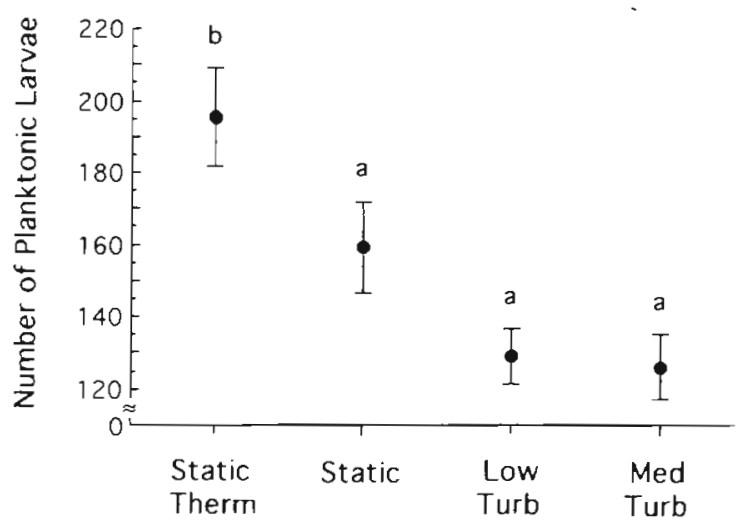

Fig. 11. Placopecten magellanicus. Number of larvae in the water column at age 28 to $29 \mathrm{~d}$ in 4 of the 5 turbulence treatments (High Turb excluded) as visualized by the Polarized Larval Recorder (PLR). Values are the means of 25 (Static, Low Turb, Med Turb) or 26 (Static Therm) profiles taken from the 3 replicate tubes over a period of $22 \mathrm{~h}$ and error bars are standard errors of the means. Letters above error bars represent the results of a Tukey test examining the effect of turbulence treatment. Values with the same letters are not significantly different (i.e. $p>0.05$ ) each treatment using the PLR give some indication of decreased larval survivorship in the Static and Med Turb tubes in comparison with the Static Therm tubes (Fig. 11). From a series of profiles taken over $22 \mathrm{~h}$ in each tube, significantly more planktonic larvae were counted in the Static Therm tubes than in the Static, Low Turb, or Med Turb treatments (1-way ANOVA on log-transformed data: $F=11.44$, df $=3,65, p \leq 0.0001$; Tukey analysis: $\mathrm{p} \leq 0.05$ ). Data retrieval from the High Turb videotapes was hindered by air bubbles, so the results for this treatment were not included in the analysis. No significant difference in numbers of larvae was evident between the Low Turb tubes and the Static Therm and Med Turb treatments, however, indicating that it is not larval survivorship alone creating differences in spat collection among treatments. Interestingly, young veligers in the High Turb tubes primarily concentrated near the surface (S. M. Gallager pers. obs.). Thus, low spat recruitment in this treatment was more likely due to reduced larval growth rates and/or lowered settlement rates/increased spat mortality due to microalgal films (see discussions above) than to decreased survivorship due to larval mixing into inhospitable bottom environments, although the latter possibility cannot be entirely discounted.

Other larval studies have alluded to the importance of larval distributions, with respect to the bottom of rearing vessels, in determining larval survivorship. Culliney et al. (1975), for instance, noted that it is beneficial to use relatively tall vessels for rearing larvae of Placopecten magellanicus. They remarked that, in greater water depths, veligers could remain well above the bottom of the containers where accumulations of debris, faeces, pseudofaeces, and protozoa led to deleterious conditions for the larvae. Barker (1978) reared larvae of the asteroids Stichaster australis and Coscinasterias calamaria under stirred conditions and remarked that water movements prevented larvae from concentrating on the bottoms of rearing containers where they were at higher risk of bacterial infection. The use of thermal gradients as a barrier to prevent larvae from mixing with the bottom of static rearing vessels may be of commercial importance to larval hatcheries aiming to increase larval survivorship and juvenile recruitment

\section{CONCLUSIONS}

Many studies have examined pectinid recruitment in the field on artificial collectors placed in the water column. Most of these have focused on the temporal and spatial variations in spatfall and how to maximize spat collection by varying the quality and quantity of collector materials. Very little scientific research has 
examined how physical factors in the water column, such as thermoclines and degree of turbulence, affect depth of larval settlement and spat recruitment. Results from this mesocosm study showed that, under conditions of limited vertical mixing and weak or no thermal stratification $\left(\varepsilon=10^{-7}\right.$ to $\left.10^{-5} \mathrm{~cm}^{2} \mathrm{~s}^{-3}\right)$, spat recruitment generally increased with increasing depth, a pattern most likely established by planktonic larval behaviour at settlement. Increasing levels of turbulence disrupted this pattern so that spat recruitment in tubes with the highest turbulence $\left(\varepsilon=10^{-4}\right.$ to $10^{-3}$ $\mathrm{cm}^{2} \mathrm{~s}^{-3}$ ) was random with respect to depth. There was no increase in recruitment at or above the 0.5 to $1.5^{\circ} \mathrm{C}$ thermoclines established in this study as was shown in a previous paper by Pearce et al. (1996) for a thermocline of $11.0^{\circ} \mathrm{C}$. Results from the present study and subsequent experiments indicate that a critical level of stratification must be attained before larvae settle at or above a vertical discontinuity. To optimize the field collection of spat, either for scientific or commercial purposes, a broad knowledge of the physical oceanographic features of the system are required. In highly stratified regions, maximum recruitment may be expected at or above the discontinuity as discussed in Pearce et al. (1996), while in weakly stratified zones with limited vertical mixing, spat collection should be enhanced by the placement of collectors at greater depths. In areas of high turbulence, spat may be collected throughout the water column if mixing conditions are prolonged or in deeper collectors if mixing is intermittent.

Results of this experiment showed that total spat recruitment was also dependent on the degree of vertical mixing. The greatest recruitment occurred in the 2 treatments with the largest thermal gradients and may have been, at least partially, the result of increased larval survivorship in these treatments. It is hypothesized that thermoclines may act as a barrier to larvae, keeping them off the bottoms of their rearing containers and out of potentially deleterious environments containing debris, detritus, faeces, bacteria, and protozoans. Further research is required to more closely examine vertical distribution of larvae, larval survivorship, and larval settlement rates under various conditions of thermal stratification to fully understand the mechanism(s) by which recruitment may be increased under thermally stratified regimes. The effect of thermal gradients on the recruitment of spat could be extremely beneficial for scallop hatchery facilities concerned with optimizing larval survivorship and juvenile recruitment.

Acknowledgements. Thanks are expressed to Y.-H. Guan, D. L. Jackson, D. L. Krailo, M. A. Silva-Serra, and B. Vercaemer for much help in the Tower Tank at various stages of the experiment. D. L. Krailo is also thanked for rearing the phytoplankton. The set up and maintenance of the Tower Tank was aided by the technical support of E. Officia, J. Whynot, D. Lawrence, and S. Fowler. Much appreciation is expressed to R. Marshall for his diligent counting of samples. Wet lab space was kindly provided by R. E. Scheibling and microalgal identification was carried out by C. Bird. We also thank W. Blanchard of the Statistical Consulting Service of Dalhousie University for help with the statistical analysis. The insightful comments of 3 anonymous reviewers are greatly appreciated. This work was carried out with funding to $E$. Bourget and R. K. O'Dor from OPEN (Ocean Production Enhancement Network, one of the 15 Networks of Centres of Excellence supported by the Government of Canada). C.M.P was funded by NSERC (Natural Sciences and Engineering Research Council), FCAR (Fonds pour la Formation de Chercheurs et l'Aide à la Recherche), OPEN, GIROQ (Groupe Interuniversitaire de Recherches Océanographiques du Québec), the O'Brien Foundation, and Université Laval.

\section{LITERATURE CITED}

Abacus Concepts (1989) SuperANOVA. Abacus Concepts Inc, Berkeley

Ambrose WG Jr, Peterson CH, Summerson HC, Lin J (1992) Experimental tests of factors affecting recruitment of bay scallops (Argopecten irradians) to spat collectors. Aquaculture 108:67-86

Baird FT Jr (1953) Observations on the early life history of the giant scallop (Pecten magellanicus). Maine Dep Sea Shore Fish Res Bull 14:1-7

Barker MF (1978) Descriptions of the larvae of Stichaster australis (Verrill) and Coscinasterias calamaria (Gray) (Echinodermata: Asteroidea) from New Zealand, obtained from laboratory culture. Biol Bull (Woods Hole) 154:32-46

Boudreau B, Simard Y, Bourget E (1991) Behavioural responses of the planktonic stages of the American lobster Homarus americanus to thermal gradients, and ecological implications. Mar Ecol Prog Ser 76:13-23

Boudreau B, Simard Y, Bourget E (1992) Influence of a thermocline on vertical distribution and settlement of post-larvae of the American lobster Homarus americanus MilneEdwards. J Exp Mar Biol Ecol 162:35-49

Bourne N (1964) Scallops and the offshore fishery of the Maritimes. Bull Fish Res Bd Can 145:1-60

Bourne N, Hodgson CA, Whyte JNC (1989) A manual for scallop culture in British Columbia. Can Tech Rep Fish Aquat Sci 1694:1-215

Brand AR, Paul JD. Hoogesteger JN (1980) Spat settlement of the scallops Chlamys opercularis (L.) and Pecten maximus (L.) on artificial collectors. J Mar Biol Assoc UK 60:379-390

Buestel D, Dao JC, Lemarié G (1979) Collecte de naissain de Pectinidés en Bretagne. Rapp PV Réun Cons Int Explor Mer 175:80-84

Burnell GM, Barnett M, O'Carroll T, Roantree V (1995) Scallop spat collection and ongrowing trials in south-west lreland. In: Lubet P, Barret J, Dao JC (eds) Fisheries, biology and aquaculture of pectinids. 8th international pectinid workshop, Cherbourg (France), May 22-29, 1991 Actes Collog 17:139-144

Caddy JF (1972) Progressive loss of byssus attachment with size in the sea scallop, Placopecten magellanicus (Gmelin). J Exp Mar Biol Ecol 9:179-190

Carriker MR (1951) Ecological observations on the distribution of oyster larvae in New Jersey estuaries. Ecol Monogr $21: 19-38$ 
Couturier C (1990) Scallop aquaculture in Canada: fact or fantasy? World Aquac 21:54-62

Cragg SM (1980) Swimming behaviour of the larvae of Pecten maximus (L.) (Bivalvia). J Mar Biol Assoc UK 60:551-564

Crisp DJ (1974) Factors influencing the settlement of marine invertebrate larvae. In: Grant PT, Mackie AM (eds) Chemoreception in marine organisms. Academic Press, New York, p 177-265

Culliney JL (1974) Larval development of the giant scallop Placopecten magellanicus (Gmelin). Biol Bull (Woods Hole) 147:321-332

Culliney JL, Boyle PJ, Turner RD (1975) New approaches and techniques for studying bivalve larvae. In: Smith WL, Chanley $\mathrm{MH}$ (eds) Culture of marine invertebrate animals. Plenum Press, New York, p 257-271

Dadswell MJ, Parsons GJ (1991) Potential for aquaculture of sea scallop, Placopecten magellanicus (Gmelin, 1791) in the Canadian Maritimes using naturally produced spat. In: Shumway SE, Sandifer PA (eds) An international compendium of scallop biology and cuiture. World aquaculture workshops, No. 1 The World Aquaculture Society, Baton Rouge, p 300-307

Dickey TD, Mellor GL (1980) Decaying turbulence in neutral and stratified fluids. J Fluid Mech 99:13-31

Feeny CF (1984) Effects of salinity on the vertical distribution of the larvae of Crassostrea virginica (Gmelin) and Ostrea equestris (Say). I Shollfish Res 4:88-89 (abstract)

Fraser DI (1983) Observations on the settlement of pectinid spat off the west coast of Scotland in 1982. Int Coun Explor Sea Comm Meet 1983/K:40:1-12

Gallager SM, Bidwell JP, Kuzirian AM (1989) Strontium is required in artificial seawater for embryonic shell formation in two species of bivalve molluscs. In: Crick RE (ed) Origin, evolution, and modern aspects of biomineralization in plants and animals. Proceedings of the fifth international symposium on biomineralization, Arlington, Texas. Plenum Press, New York, p 349-366

Gallager SM, Manuel JL, Manning DA, O'Dor R (1996) Ontogenetic changes in the vertical distribution of giant scallop larvae, Placopecten magellanicus, in 9-m deep mesocosms as a function of light, food, and temperature stratification. Mar Biol 124:679-692

Harder W (1.968) Reactions of plankton organisms to water stratification. Limnol Oceanogr 13:156-168

Harvey M, Bourget E, Miron G (1993) Settlement of Iceland scallop Chlamys islandica spat in response to hydroids and filamentous red algae: field observations and laboratory experiments. Mar Ecol Prog Ser 99:283-292

Heasman MP, O'Connor WA, Frazer AW (1994) Detachment of commercial scallop Pecten fumatus, spat from settlement substrates. Aquaculture 123:401-407

Hortle ME, Cropp DA (1987) Settlement of the commercial scallop, Pecten fumatus (Reeve) 1855, on artificial collectors in eastern Tasmania. Aquaculture 66:79-95

Kaartvedt S, Aksnes DL, Egge JK (1987) Effect of light on the vertical distribution of Pecten maximus larvae. Mar Ecol Prog Ser 40:195-197

Kenchington $E_{1}$ Tètu $C_{i}$ Mohn R (1991) Preliminary investigations of juvenile scallops (Placopecten magellanicus) in Nova Scotia inshore habitats. Can Man Rep Fish Aquat Sci 2123:1.-32

Kiørboe T, Saiz E (1995) Planktivorous feeding in calm and turbulent environments, with emphasis on copepods. Mar Ecol Prog Ser 122:135-145

Larsen PF, Lee RM (1978) Observations on the abundance, distribution and growth of postlarval sea scallops, Placopecten magellanicus, on Georges Bank. Nautilus 92:
$112-116$

Mann R, Campos BM, Luckenbach MW (1991) Swimming rate and responses of larvae of three mactrid bivalves to salinity discontinuities. Mar Ecol Prog Ser 68:257-269

Manuel JL (1996) Population and temporal variations in the vertical migrations of scallop (Placopecten magellanicus) veligers. $\mathrm{PhD}$ thesis, Dalhousie University, Halifax

Manuel JL, Burbridge S, Kenchington EL, Ball M, O'Dor RK (1996a) Veligers from two populations of scallop Placopecten magellanicus exhibit different vertical distributions in the same mesocosm. J Shellfish Res 15:251-257

Manuel JL, Gallager SM, Pearce CM, Manning DA, O'Dor RK (1996b) Veligers from different populations of sea scallop Placopecten magellanicus have different vertical migration patterns. Mar Ecol Prog Ser 142:147-163

Margus D (1991) Settlement of pectinid larvae in the Krka River estuary of Yugoslavia. In: Shumway SE, Sandifer PA (eds) An international compendium of scallop biology and culture. World aquaculture workshops, No. 1. The World Aquaculture Society, Baton Rouge, p 37-42

Maru K, Obara A, Kikuchi K, Okesaku H (1973) Studies on the ecology of the scallop, Patinopecten yessoensis (Jay) 3. On the diurnal vertical distribution of scallop larvae. Scl Rep Hokkaido Fish Exp Sta 15:33-52

Mason J (1969) The growth of spat of Pecten maximus (L.). Int Coun Explor Sea Comm Meet 1969/K:32:1-5

Mason J (1983) Scallon and queen fisheries in the British Isles Fishing News Books Ltd, Farnham

Merrill AS, Edwards RL (1975) Observations on mollusks from a navigation buoy with special emphasis on the sea scallop Placopecten magellanicus. Nautilus 89:116-123

Merrill AS, Posgay JA (1967) Juvenile growth of the sea scallop, Placopecten magellanicus. Annu Rep Am Malacol Union 1967:51-52 (abstract)

Mileikovsky SA (1973) Speed of active movement of pelagic larvae of marine bottom invertebrates and their ability to regulate their vertical position. Mar Biol 23:11-17

Naidu KS (1970) Reproduction and breeding cycle of the giant scallop Placopecten magellanicus (Gmelin) in Port au Port Bay, Newfoundland. Can J Zool 48:1003-1012

Naidu KS (1991) Fisheries and aquaculture: sea scallop, Placopecten magellanicus. In: Shumway SE (ed) Scallops: biology, ecology and aquaculture. Developments in aquaculture and fisheries science, Vol 21. Elsevier, New York, p 861. -897

Naidu KS, Cahill FM (1986) Culturing giant scallops in Newfoundland waters. Can Man Rep Fish Aquat Sci 1876:1-23

Naidu KS, Cahill FM. Lewis DB (1981) Relative efficacy of two artificial substrates in the collection of sea scallop (Placopecten magellanicus) spat. J World Maric Soc 12 $165-171$

Naidu KS, Fournier R, Marsot P, Worms J (1989) Culture of the sea scallop, Placopecten magellanicus: opportunities and constraints. In: Boghen AD (ed) Cold-water aquaculture in Atlantic Canada. The Canadian Institute for Research on Regional Development. The Tribune Press Ltd, Sackville, p 211-239

Naidu KS, Scaplen R (1979) Settlement and survival of giant scallop. Placopecten magellanicus, larvae on enclosed polyethylene film collectors. In: Pillay TVR, Dill WA (eds) Advances in aquaculture. Fishing News Books Ltd, Farnham, p 379-381

Oshurkov VV, Shilin MB, Oksov IV, Smirnov BR (1982) Seasonal dynamics of meroplankton in Chupa Inlet (White Sea). Sov J Mar Biol 8:1-8

Parsons GJ, Dadswell MJ, Roff JC (1993) Influence of biofilm on settlement of sea scallop. Placopecten magellanicus 
(Gmelin, 1791), in Passamaquoddy Bay, New Brunswick, Canada. J Shellfish Res 12:279-283

Pearce CM (1996) Fixation des larves du pétoncle géant (Placopecten magellanicus): effets du substrat et de la stratification de la colonne d'eau. PhD thesis, Laval University, Sainte-Foy

Pearce CMi, Bourget E (1996) Settlement of larvae of the giant scallop, Placopecten magellanicus (Gmelin), on various artificial and natural substrata under hatchery-type conditions. Aquaculture 141:201-221

Pearce CM, Gallager SM, Manuel JL Manning DA, O'Dor RK, Bourget E (1996) Settlement of larvae of the giant scallop, Placopecten magellanicus, in 9-m deep mesocosms as a function of temperature stratification, depth, food, and substratum. Mar Biol 124:693-706

Peña JB, Mestre S, Farias A (1995) Pectinid settlement on artificial collectors in Castellon, east Spain, in 1990. In: Lubet P, Barret J, Dao JC (eds) Fisheries, biology and aquaculture of pectinids. 8th international pectinid workshop, Cherbourg (France), May 22-29, 1991. Actes Colloq 17: $111-114$

Pouliot F, Bourget E, Fréchette M (1995) Optimizing the design of giant scallop (Placopecten magellanicus) spat collectors: field experiments. Mar Biol 123:277-284

Raby D, Lagadeuc Y, Dodson JJ, Mingelbier M (1994) Relationship between feeding and vertical distribution of bivalve larvae in stratified and mixed waters. Mar Ecol Prog Ser 103:275-284

Robinson SMC, Martin JD, Chandler RA, Parsons GJ, Couturier CY (1992) Larval settlement patterns of the giant scallop (Placopecten magellanicus) in Passamaquoddy Bay, New Brunswick. Can Atl Fish Sci Adv Comm Res Doc No. 92/115:1-26

Ruiz-Verdugo CA, Cáceres-Martínez C (1991) Experimental spat collection of scallops Argopecten circularis (Sowerby, 1835) and Pecten vogdesi (Arnold, 1906) on a filament substrate in Falsa Bay, B.C.S. Mexico. In: Shumway SE, Sandifer PA (eds) An international compendium of scallop biology and culture. World aquaculture workshops, No. 1. The World Aquaculture Society, Baton Rouge, p 21-27

Ruzzante DE, Zaixso HE (1985) Settlement of Chlamys tehuelchus (D'Orb.) on artificial collectors. Seasonal changes in spat settlement. Mar Ecol Prog Ser 26:195-197

Sause BL, Gwyther D, Burgess D (1987) Larval settlement, juvenile growth and the potential use of spatfall indices to predict recruitment of the scallop Pecten alba Tate in Port Phillip Bay, Victoria, Australia. Fish Res 6:81-92

Scrope-Howe S, Jones DA (1986) The vertical distribution of zooplankton in the western Irish Sea. Estuar Coast Shelf Sci 22:785-802

Silva-Serra MA (1995) Early life history traits of Placopecten magellanicus (Gmelin): behaviours, lipid condition and vertical distribution of veligers at micro- and meso-scales. PhD thesis, Dalhousie University, Halifax

Silva-Serra MA, O'Dor RK (1988) Active depth regulation by the sea scallop larvae of Placopecten magellanicus? Bull Can Soc Zool 19:36 (abstract)

Sinclair M, Mohn RK, Robert G, Roddick DL (1985) Considerations for the effective management of Atlantic scallops Can 'Tech Rep Fish Aquat Sci 1382:1-113

Sokal RR, Rohlf FJ (1981) Biometry, 2nd edn. WH Freeman and Company, New York

Sulkin SD (1984) Behavioral basis of depth regulation in the larvae of brachyuran crabs. Mar Ecol Prog Ser 15 $181-205$

Sumpton WD, Brown IW, Dredge MCL (1990) Settlement of bivalve spat on artificial collectors in a subtropical embayment in Queensland, Australia. J Shellfish Res 9:227-231

Thiébaut E, Dauvin JC, Lagadeuc Y (1992) Transport of Owenia fusiformis larvae (Annelida: Polychaeta) in the Bay of Seine. I. Vertical distribution in relation to water column stratification and ontogenic vertical migration. Mar Ecol Prog Ser 80:29-39

Thorson G (1964) Light as an ecological factor in the dispersal and settlement of larvae of marine bottom invertebrates Ophelia 1:167-208

Thouzeau G (1991) Experimental collection of postlarvae of Pecten maximus (L.) and other benthic macrofaunal species in the Bay of Saint-Brieuc, France. I. Settlement patterns and biotic interactions among the species collected. J Exp Mar Biol Ecol 148:159-179

Thouzeau G, Robert G, Smith SJ (1991) Spatial variability in distribution and growth of juvenile and adult sea scallops Placopecten magellanicus (Gmelin) on eastern Georges Bank (Northwest Atlantic). Mar Ecol Prog Ser 74:205-218

Tremblay MJ (ed) (1988) A summary of the proceedings of the Halifax sea scallop workshop, August 13-14, 1987 Can Tech Rep Fish Aquat Sci 1605:1-12

Tremblay MJ, Sinclair MM (1988) The vertical and horizontal distribution of sea scallop (Placopecten magellanicus) larvae in the Bay of Fundy in 1984 and 1985. J Northw Atl Fish Sci 8:43-53

Tremblay MJ, Sinclair M (1990a) Sea scallop larvae Placopecten magellanicus on Georges Bank: vertical distribution in relation to water column stratification and food. Mar Ecol Prog Ser 61:1-15

Tremblay MJ, Sinclair M (1990b) Diel vertical migration of sea scallop larvae Placopecten magellanicus in a shallow embayment. Mar Ecol Prog Ser 67:19-25

Ventilla RF (1977) A scallop spat collector trial of the northern Ardnamurchan coast. White Fish Authority, Field Rep 485:1-16

Wallace JC (1982) The culture of the Iceland scallop, Chlamys islandica (O. F. Müller) I. Spat collection and growth during the first year. Aquaculture 26:311-320

Walossek D (1991) Chlamys patagonica (King \& Broderip 1832), a long 'neglected' species from the shelf off the Patagonia coast. In: Shumway SE, Sandifer PA (eds) An international compendium of scallop biology and culture. World aquaculture workshops, No. 1 The World Aquaculture Society, Baton Rouge, p 256-263

Wilkinson L (1992) SYSTAT: the system for statistics. SYSTAT Inc, Evanston, IL

Xu H, Xu B, Ji W (1991) Component of bacteria and their effects on settlement substratum of larvae of scallop. J Fish China 15:117-123 (in Chinese, with English abstract)

Young CM, Chia FS (1987) Abundance and distribution of pelagic larvae as influenced by predation, behavior, and hydrographic factors. In: Giese AC, Pearse JS, Pearse VB (eds) Reproduction of marine invertebrates, Vol IX, General aspects: seeking unity in diversity. Blackwell Scientific Publications, Palo Alto, and The Boxwood Press, Pacific Grove, p 385-463

Young PC, McLoughlin RJ, Martin RB (1992) Scallop (Pecten fumatus) settlement in Bass Strait, Australia. J Shellfish Res 11:315-323

Young PC, McLoughlin R, Martin R (1995) Vertical distribution of larvae and spat of the commercial scallop, Pecten fumatus. In: Lubet P, Barret J, Dao JC (eds) Fisheries, biology and aquaculture of pectinids. 8 th international pectinid workshop, Cherbourg (France), May 22-29, 1991 Actes Colloq 17:199-205 